\title{
ARTE DIALÓGICA E EPISTOLAR SEGUNDO AS EPÍSTOLAS MORAIS A LUCÍLIO
}

\author{
MARCOS MARTINHO DOS SANTOS* \\ Faculdade de Filosofia, Letras e Ciências Humanas \\ da Universidade de São Paulo
}

\begin{abstract}
RESUMO: Trata-se de reunir os preceitos referentes ao discurso filosófico que Sêneca enuncia nas Epístolas. Primeiro, os preceitos do gênero dialógico (sermo ou diálogos), de que a epistula é uma das espécies. Depois, os preceitos do ofício de ensinar, próprio do filósofo, que se opõe, então, ao poeta, a quem cabe deleitar, e ao orador, a quem cabe comover. Enfim, os preceitos da arte dialógica ou epistolar segundo os quais a matéria filosófica deve ser grandiosa, e a elocução, negligenciada. Tal negligência, porém, é mesmo diligência para o filósofo, ou melhor, é efeito, e não defeito da elaboração do discurso. A arte dialógica revela-se, então, uma arte de dissimular a arte.
\end{abstract}

PALAVRAS-CHAVE: diálogo; epístola; discurso filosófico; ofício de ensinar; arte dialógica; dissimulação da arte.

\section{Introdução}

Sêneca, em algumas epístolas, preceitua o que e como deve discursar e escrever o filósofo. ${ }^{1}$ Propomo-nos, pois, reunir aqui tais preceitos, que lá estão dispersos, e confrontar, se não identificar esses, que não são particulares do Autor, com outros, genéricos, da retórica e poética antiga; pois se para o orador e poeta já se haviam redigido, muito antes de Sêneca, artes retóricas e poéticas, para o filósofo, porém, só se redigiu muito depois o que se poderia chamar arte dialógica (cf. infra). Ora, o estudo dos preceitos que orientam a matéria e elocução filosófica na antigüidade é importante, se não imprescindível para o juízo dos textos filosóficos que os antigos nos legaram, entre os quais as Epístolas morais a Lucílio, e já que antes de Sêneca não se compusera uma arte dialógica, só há, por assim dizer, recompor-se os preceitos subjacentes àquele texto. Enfim, tal estudo pretende-se, aqui, fiel à lição 
das Epistolas de Sêneca, de modo que as referências a estas sirvam, mais que a ilustrálo, a orientá-lo; ou seja, o estudo não precede a lição, antes a lição o precede a ele.

\section{História das artes dialógicas}

Assim como é dialógica a epístola (cf. infra), assim também a arte epistolar. Ora, a primeira arte epistolar ou, como lhe chamaram seus autores, arte do ditado (ars dictaminis) que se confeccionou em latim parece ter sido o Breviarium dictaminis, de Albérico de Monte Cassino, do séc. XI d.C.; depois desta, muitas outras saíram à luz, entre as quais a Summa dictaminis, de Bernardo Meung, do séc. XII d.C., e a Ars dictaminis, de Conrado de Mure, do séc. XIII d.C.. A que distância, pois, está a origem das artes poéticas e retóricas, uma vez que, já no séc. IV a.C., deparamos a Poética e Retórica de Aristóteles e, antes mesmo, as artes poética e retórica esparsas de Platão, aquela, no Ion e passos dos "Livros 2, 3 e 10" da República, e esta, no Fedro e Górgias.

Mas é possível dizer que a arte do ditado, se não floresce com os escritores de artes mais antigos, jaz de algum modo embrionária nestes; é o que se pode concluir com Cícero (séc. I a.C.). Este, de modo geral, afirma que os mestres de retórica não tratam todos os preceitos da invenção e elocução (Cic. De or. 112 52). De modo particular, porém, afirma que não tratam os preceitos da conversa filosófica (sermo), mas tão-somente os da contenda oratória (contentio; id. Off. 137132 - 38 137). Demais, diz ainda que é possivel adaptar-se os preceitos desta àquela (id. Off. 137 132).

Assim, pois, passamos à reunião dos preceitos epistolares que se lêem nas Epistolas de Sêneca, em particular nas "Epístolas 38, 40, 52, 58, 59, 75, 100, 108, 114 e 115", a fim de os confrontar com outros que se lêem em textos de retórica, por exemplo, na Retórica a Herênio e noutros de Cícero, e em textos de poética, por exemplo, na Epistola aos Pisões, de Horácio.

\section{Gênero dialógico e espécie epistolar}

Sêneca, ao tratar o discurso adequado ao filósofo (cf. 100 1: de philosopho agi), designa-o tanto pela palavra latina sermo:

Plurimum proficit sermo, quia minutatim inrepit animo [...]. Philosophia bonum consilium est: consilium nemo clare dat (38 1) 
Muito mais aproveita a conversa (sermo), pois que sub-repticiamente se imiscui no ânimo [...]. Filosofia é bom conselho; ninguém dá conselho clamorosamente, ${ }^{2}$

como pela grega diálogos:

Scripsit [sc. T. Livius] enim et dialogos, quos non magis philosophiae adnumerare possis quam historiae, et ex professo philosophiam continentis libros (100 9)

Escreveu, sim, [T. Lívio] tanto diálogos (dialogos), que se podem contar não mais no número dos filosóficos que no dos históricos, como livros de conteúdo professamente filosófico, ${ }^{3}$

e qualifica-o, de modo mais particular, pelo adjetivo familiaris:

Plurimum proficit sermo, quia minutatim inrepit animo: disputationes praeparatae et effusae audiente populo plus habent strepitus, minus familiaritatis (38 1)

Muito mais aproveita a conversa, pois que sub-repticiamente se imiscui no ânimo; as disputas preparadas e desferidas em audição pública têm mais estrépito, menos familiaridade. ${ }^{4}$

Sermo, porém, opõe-no Sêneca a contio, isto é, à espécie deliberativa do discurso oratório ou contentio:

Plurimum proficit sermo, quia minutatim inrepit animo [...]. Aliquando utendum est et illis, ut ita dicam, contionibus, ubi qui dubitat inpellendus est (38 1; cf. 11 4: Nihil erat mollius ore Pompei; numquam non coram pluribus rubuit, utique in contionibus. Fabianum, cum in senatum testis esset inductus, erubuisse memini, et hic illum mire pudor decuit)

Muito mais aproveita a conversa (sermo), pois que sub-repticiamente se imiscui no ânimo [...]. Às vezes é para usar ainda dos - por assim dizer - comícios (contionibus), quando é para impelir quem duvida (cf.: Nada era mais maleável que a oralidade de Pompeu; sempre, sim, se ruborizava cara à cara com muitos, ainda mais nos comícios (contionibus). Fabiano, quando conduzido como testemunha ao senado, enrubesceu, lembro-me, e este pudor foi para ele admiravelmente decoroso), ${ }^{5}$ 
pois assim como o sermo é familiaris, a contentio é popularis (40 4: haec popularis [sc. oratio]):

Plurimum proficit sermo [...]: disputationes [...] effusae audiente populo plus habent strepitus, minus familiaritatis (38 1)

Muito mais aproveita a conversa [...]; as disputas [...] desferidas em audição pública (audiente populo) têm mais estrépito, menos familiaridade (familiaritatis).

Daí, pois, Sêneca opõe o discurso do filósofo ao do orador:

Vix oratori permiserim talem dicendi velocitatem (40 8)

Mal permitira ao orador tal velocidade discursiva;

Sed ista oratoribus reliquissem (75 2)

Mas teria relegado isso aos oradores;

Deest illis [sc. Fabiani Papiri] oratorius vigor (100 8; cf. 100 9)

Falta àquilo [que é de Papírio Fabiano] o vigor oratório. ${ }^{6}$

Ademais, opõe ainda o discurso do filósofo ao do poeta, quer pelo gênero poético deste (114 14: poeticis), ${ }^{7}$ quer pela espécie dramática:

Intersit aliquid inter clamorem theatri et scholae (52 12)

Alguma distinção há entre o clamor do teatro e o da escola;

Quidam veniunt [sc. in philosophi scholam] [...] sicut in theatrum [...] ducimur (108 6)

Alguns chegam [à escola do filósofo] [...] assim como ao teatro [...] somos conduzidos. ${ }^{8}$

Enfim, opõe o discurso do filósofo, a um tempo só, ao discurso genérico do orador e aos discursos específicos do poeta tragediógrafo ou comediógrafo:

Sit aliquid oratorie acre, tragice grande, comice exile (100 10)

Haja algo oratoriamente acerbo, tragicamente grande, comicamente estreito, 
ou ainda, opõe aquele discurso, que sobressai pelo animus, aos das outras artes, que sobressaem pelo ingenium:

Aliae artes ad ingenium totae pertinent, hic animi negotium agitur (75 5; cf. 75 3)

As outras artes pertencem inteiras ao engenho, aqui [na filosofia] tratam-se os negócios da alma,

ou enfim, opõe aquele discurso, familiar, aos das outras artes, populares:

Relinquantur istae voces illis artibus quae propositum habent populo placere: philosophia adoretur (52 13)

Releguem-se essas vozes àquelas artes que têm por propósito aprazer o povo; a filosofia seja adorada.

Ademais, assim como o do orador se distingue por espécies, por exemplo, pela deliberativa, que Sêneca designa pela palavra contio (38 1), assim também o discurso do filósofo; é o que se vê destes passos:

Merito exigis ut hoc inter nos epistularum commercium frequentemus. Plurimum proficit sermo (38 1; cf. 66 4)

Merecidamente exiges que freqüentemos este comércio de epístolas (epistularum) entre nós. Muito mais aproveita a conversa (sermo);

Qualis sermo meus esset [...] tales esse epistulas meas volo (75 1)

Qual seria minha conversa (sermo) [...], tais quero que sejam minhas epístolas (epistulas).

Assim, se o gênero de discurso adequado ao filósofo é o sermo, a espécie é, entre outras, a epistula. ${ }^{9}$

Em suma, Sêneca opõe filósofo tanto a poeta como a orador; daí, porém, opõe o gênero do sermo tanto ao gênero poético como ao gênero oratório; daí, enfim, opõe a espécie da epistula tanto às espécies do drama, isto é, à tragédia e comédia, como às espécies da contentio, por exemplo, à contio. Ora, os mesmos gêneros, assim opostos, já comparecem na exposição que se lê no Orador de Cícero. Lá, ao tratar o gênero dos filósofos, o dos sofistas, o dos poetas, o dos historiadores 
e o dos oradores, Cícero arranja-os em três, ou melhor, opõe ao gênero dos oradores, ${ }^{10}$ por um lado, o dos filósofos ${ }^{11} \mathrm{e}$, por outro, o dos sofistas, ${ }^{12}$ a que prende, por sua vez, o dos historiadores ${ }^{13}$ e o dos poetas ${ }^{14}$ (cf. Cic. Or. 21 72).

\section{Gênero humilde}

A par disso, porém, Sêneca ainda articula o discurso filosófico com outro sistema de gêneros tripartite (cf. Cic. Or. 21 69: tripertitae varietatis). Então, qualifica o discurso do filósofo por humilis (100 8), se não por submissus (38 1), remissus (115 2), tenuis (cf. 46 2: tenor; 100 8: tenorem), lenis (40 2; 100 5; 115 18), placidus (100 8; cf. 114 15), planus (100 8)..$^{15}$ Tais adjetivos, porém, são empregados por Sêneca em sentido positivo, ou melhor, para caracterizar a virtude própria do discurso filosófico, ao passo que Lucílio os pode empregar em sentido negativo, ou melhor, para caracterizar o vício próprio do mesmo discurso:

Humilia praeterea tibi videri dicis omnia [sc. Fabiani Papiri] et parum erecta: quo vitio carere eum iudico (100 8)

Além disso, dizes que tudo [que é de Papírio Fabiano] humilde te parece e pouco ereto, vício de que julgo ele carecer.

É que Sêneca, por pensar no filósofo, tem por adequado o gênero humilde; Lucílio, por pensar mais no orador que no filósofo, tem-no por desadequado. Pois assim como no homem a cada virtude se avizinha um vício, por exemplo, à coragem a temeridade, à cautela a covardia (45 7), assim também no discurso. ${ }^{16}$ Por isso, o mesmo que no discurso é enxuto para Sêneca, para Lucílio é seco:

Non mehercules ieiuna esse et arida volo quae de rebus tam magnis dicentur (75 3)

Não quero, por Hércules, que seja mirrado e árido o que se diz de casos tão grandes!;

Nam illa quoque inopia et exilitas minus intentum auditorem habet (40 3)

Pois também aquilo que é desprovido e estreito retém menos a atenção do ouvinte;

o mesmo que a Sêneca agrada como plano ou pleno, a Lucílio desagrada como raso ou duro (cf. 100 8: nec depressa sed plana; 100 12: non solida, sed plena; infra n. 17). 
Mas o próprio Sêneca, por sua vez, tem por desadequado o que é próprio do discurso poético e oratório. Para ele, pois, o discurso do poeta qualifica-se, não pela virtude, isto é, como macio, mas pelo vício, isto é, como mole (cf. 114 8: mollem [...] non mitem), ou ainda, não como fluente (cf. 100 1: fluxerit; 114 15: effluxit; 115 18: fluens), mas como flutuante (cf. 114 4: difflueret; 40 12: profluat); assim também, o discurso do orador é, não amplo, mas túmido (cf. 59 5: tumidi):

Quare quibusdam temporibus provenerit corrupti generis oratio quaeris et quomodo in quaedam vitia inclinatio ingeniorum facta sit, ut aliquando inflata explicatio vigeret, aliquando infracta (114 1)

Por isso, inquires os tempos de que proveio o gênero corrupto de oração, e o modo como se fez a inclinação dos engenhos a alguns vícios, de modo que às vezes vigorasse exposição inflada, às vezes enfraquecida. ${ }^{17}$

Seja pelas virtudes, porém, seja pelos vícios, Sêneca manuseia gêneros de um sistema tripartite que Cícero recorre amiúde. Segundo o Orador, pois, há três gêneros de discurso, a saber: um, o que se diz grave ou pleno ou sublime ou amplo ou grandíloquo ou veemente ou copioso; outro, o que se diz sutil ou tênue ou atenuado ou compresso ou remisso ou humilde; terceiro, o que se diz médio ou medíocre ou temperado ou módico ou intermediário (Cic. De or. 345 177, 52 199, 55 212; Br. 55 201-2; Or. 520 - 6 22, 16 53, 21 69, 2375 - 28 99). ${ }^{18}$ Também a Retórica a Herênio expõe os três gêneros (Her. 4 11-6), designando-os por figura grauis, mediocris e extenuata (ib. 4 11) e equiparando a extenuata com sermo demissus (ib. 4 14). Demais, refere os vícios que confinam com cada figura e a cada uma se aproximam (ib. 4 15: finituma et propinqua uitia), designando o da figura grauis por genus sufflatum, turgidum, inflatum, tumidum (ib. 4 15) - em Sêneca lê-se tumidi (59 5) e inflata (114 1) -; o da mediocris, por genus errans, dissolutum, fluctuans (Her. 4 16) - em Sêneca lê-se soluta, difflueret e errantem (114 4) -; o da extenuata, por genus aridum (Her. 4 16) - em Sêneca lê-se arida (75 3) -.

Enfim, é lição comum a Cícero e Horácio o considerar cada gênero por sua uis, isto é, por seu vigor. ${ }^{19}$ Então, o discurso grave, ou contentio, define-se pelo vigor máximo, ${ }^{20}$ ao passo que o sutil, ou sermo, pela ausência daquele vigor. ${ }^{21}$ Assim, para Sêneca, que pensa antes no sermo que na contentio, o vigor oratório vê-se, não pela virtude, mas pelo vício, isto é, não como máximo (cf. Cic. Or. 23 76: maximis viribus) ou sumo (cf. id. De or. 160 255: summa vis), mas como violento e demasiado: violenta ista et nimia vis (46 8; cf. 100 10: violenta). 


\section{Ofício de ensinar}

Cícero equipara os gêneros aos ofícios dos discursadores. ${ }^{22}$ Então, dá ao discurso sutil o docere ou ensinar, ao módico o delectare ou deleitar, ao veemente o monere ou comover, ${ }^{23}$ e do remisso, em particular, diz que pode ensinar, não comover, ${ }^{24}$ assim como do filósofo diz que é próprio o ensinar, não o incitar nem o cativar. ${ }^{25}$ Ora, Sêneca, por pensar no filósofo e, daí, no sermo ou discurso remisso, preceitua o docere ou ensinar (cf. 40 3: docenti), quanto a quem diz, e ainda o discere ou aprender (cf. 38 1: discat), quanto a quem ouve. Docere, porém, equipara-o a prodesse ou "ser proveitoso (a alguém)", bem como discere a proficere ou "tirar proveito (de alguém)":

'Idem' inquit [sc. Attalus] 'et docenti et discenti debet esse propositum, ut ille prodesse velit, hic proficere' (108 3; cf. 108 6: profectu; 100 11: profectum)

"O mesmo", insiste [Átalo], "tanto a quem ensina como a quem aprende deve ser o propósito: que aquele queira ser proveitoso; este, tirar proveito";

daí, também o prodesse e o proficere prende ao sermo ou discurso remisso:

Plurimum proficit sermo [...] sed [sc. ubi hoc agendum est] ut discat, ad haec submissiora verba veniendum est (38 1)

Muito mais aproveita a conversa [...], mas [quando é para tratar] disto: de que se aprenda, é para achegar-se destas palavras remissas.

Por outro lado, Sêneca também refere o deleitar e o comover. Aquele prende-o ao discurso poético:

Quidam veniunt [sc. in philosophi scholam] [...] sicut in theatrum voluptatis causa ad delectandas aures oratione vel voce vel fabulis ducimur (108 6; cf. ib.: oblectamento; 75 7: oblectas)

Alguns chegam [à escola do filósofo] [...] assim como ao teatro somos conduzidos por causa da volúpia, para se deleitarem os ouvidos com a oração ou a voz ou as fábulas; ${ }^{26}$

bem como o placere ou aprazer, termo equiparável a delectare, o prende às outras artes: 
Relinquantur istae voces illis artibus quae propositum habent populo placere: philosophia adoretur (52 13)

Releguem-se essas vozes àquelas artes que têm por propósito aprazer o povo; a filosofia seja adorada.

Daí, porém, Sêneca opõe aproveitar a deleitar: ${ }^{27}$

Librorum istic inopiam esse quereris. Non refert quam multos sed quam bonos habeas: lectio certa prodest, varia delectat (45 1)

Queixas-te de que aí não há provisão de livros. Não importa quão muitos, mas quão bons tenhas; a leitura, se certa, aproveita, se vária, deleita;

Non delectent verba nostra, sed prosint (75 5)

Não deleitem as nossas palavras, mas aproveitem.

De certo modo, distingue entre o proveitoso e o prazeroso na medida em que este seria de quem diz o que agrada ao ouvinte, e aquele de quem diz o que agrada a si:

Denique illud praestabit, ut liqueat tibi illum sensisse quae scripsit. Intelleges hoc actum ut tu scires quid illi placeret, non ut ille placeret tibi. Ad profectum omnia tendunt, ad bonam mentem: non quaeritur plausus (100 11)

Enfim, isto sobressairá: a clareza de ter ele sentido o que escreveu. Entenderás que isto se fez para que soubesses tu o que a ele lhe aprazia, não para que ele a ti te aprouvesse. Ao proveito tende tudo, à boa mente; não se procura o aplauso.

O comover, por sua vez, Sêneca prende-o ao discurso oratório, equiparando-o, ademais, ao rapere ou arrebatar:

Movere vult turbam [sc. haec popularis oratio] et inconsultas aures impetu rapere (40 4; cf. 40 5: raptim; 52 14: commoveantur)

Quer [esta oração popular] comover a turba e arrebatar com ímpeto ouvidos inconsultos.

Daí, porém, o adjetivo rapidus tanto se prende à uis ou vigor oratório (cf. supra) como se opõe ao ensinar, próprio do sermo filosófico: 
$[U t]$ istam vim dicendi rapidam atque abundantem aptiorem esse circulanti quam agenti rem magnam ac seriam docentique (40 3)

Que esse vigor arrebatador e abundante do discurso é mais apto a quem rodeia que a quem trata e ensina sério e grande caso.

Já na "Epístola 38" parece que o termo rapere faz paronomásia com inrepere ou subreptício (cf. 38 1: inrepit; 38 2: rapiat; cf. Cic. Or. 28 97: inrepit), pelo que é de reparar o vínculo, que lá se estabelece, deste ao sermo:

Quia minutatim inrepit [sc. sermo] animo (38 1)

Pois que sub-repticiamente se imiscui no ânimo.

De certo modo, Sêneca distingue entre sermo e contio na medida em que aquele se presta a ensinar quem já quer, e a contio a estimular quem ainda não quer aprender:

Aliquando utendum est et illis, ut ita dicam, contionibus, ubi qui dubitat inpellendus est; ubi vero non hoc agendum est, ut velit discere, sed ut discat, ad haec submissiora verba veniendum est (38 1)

Às vezes, é para usar ainda dos - por assim dizer - comícios (contionibus), quando é para impelir quem duvida; quando, porém, não é para tratar isto: que se queira aprender, mas [isto]: que se aprenda, é para achegar-se destas palavras remissas.

\section{Arte dialógica e epistolar}

Cícero divide a uis do orador em duas partes: na res, ou caso, e nos uerba, ou palavras (Cıc. Part. 13 ), e nega que possam alcançar a eloqüência tanto o que só cuida do caso como o que só cuida das palavras (id. Or. 5 17; cf. 3 10). Ora, em geral, este é o poeta, ${ }^{28}$ aquele o filósofo; ${ }^{29}$ o poeta que floreia as palavras (cf. id. Or. 27 96: florens orationis [...] genus), o filósofo que sutiliza o caso (cf. id. Or. 21 69: subtile [sc. genus dicendi]). ${ }^{30}$ Com essa lição concorda a de muitos passos das Epístolas de Sêneca, que, por pensar mais no filósofo que no poeta, tanto ataca o discurso florido (cf. 114 16: floridae) como defende a primazia do caso sobre as palavras:

A rebus studium transferendum est ad verba (40 14)

É para transferir o estudo dos casos às palavras; 
$<A t>$ ad rem commoveantur, non ad verba composita (52 14)

Mas comovam-se com o caso, não com a composição das palavras;

Rei aptata [sc. sunt omnia] (59 5)

Adaptado ao caso [está tudo];

Qui simpliciter et demonstrandae rei causa eloquebantur (59 6)

Que falavam com simplicidade e por causa de demonstrar o caso;

Circa verba occupatus es? iamdudum gaude si sufficis rebus (75 7)

Estás ocupado com as palavras? Desde já te regozija se és suficiente aos casos;

Aliqui tamen et cum pugillaribus veniunt [sc. in philosophi scholam], non ut res excipiant, sed ut verba, quae tam sine profectu alieno dicant quam sine suo audiunt (108 6)

Alguns, todavia, até com os pugilares chegam [à escola do filósofo], não para que os casos, mas para que as palavras escrevam, as quais tanto digam sem proveito alheio como ouvem sem o seu;

Rapit illos instigatque rerum pulchritudo, non verborum inanium sonitus (108 7)

Arrebata e instiga aqueles a beleza dos casos, não o som de palavras inanes.

Do filósofo, em particular, diz Cícero, de um lado, que o caso é magnus ou grandioso (cf. Cic. Or. 4 14: magnae variaeque res), e as palavras, negligenciadas; ${ }^{31}$ de outro, porém, diz que tal negligência é mesmo diligência para o filósofo, ${ }^{32}$ como se na mesma falta de graça das palavras residisse a graça do discurso filosófico. ${ }^{33}$ Também com essa lição concorda a de muitos passos das Epístolas de Sêneca. Este, de um lado, preza o cuidado com o caso, que qualifica por magnus (cf. 40 3: rem magnam ac seriam; 52 11: rerum magnitudo; 75 3: de rebus tam magnis; 100 10: rerum [...] magnitudini), ${ }^{34} \mathrm{e}$ menospreza o cuidado com as palavras, que tacha de pusillae ou pequeninas:

Vis illum [sc. Fabianum Papirium] adsidere pusillae rei, verbis (100 10)

Queres que ele [=Papírio Fabiano] insista em coisa pequenina: nas palavras; 
Nimis anxium esse te circa verba et compositionem, mi Lucili, nolo (115 1) Não te quero, Lucílio meu, demasiado ansioso pelas palavras e composição;

Cuiuscumque orationem videris sollicitam et politam, scito animum quoque non minus esse pusillis occupatum (115 2)

Cada qual, cuja oração vires que é solícita e polida, saberás que tem o ânimo não menos ocupado em pequenezas.

De outro lado, explica a Lucílio que é na negligência das palavras que reside a graça própria do discurso lenis ou leve:

Puta esse quod dicis et effundi verba [sc. Fabiani Papiri], non figi. Primum habet ista res suam gratiam et est decor proprius orationis leniter lapsae (100 1) Pensa que seja isso que dizes, e que as palavras [de Papírio Fabiano] sejam difusas, não firmes. Primeiro, tem tal coisa a sua graça e é decoro próprio da oração que desliza levemente,

pelo que corrige o valor negativo que Lucílio, por pensar mais no orador que no filósofo, empresta ao termo neglegens:

Fabianus non erat neglegens in oratione sed securus (100 5)

Fabiano não era negligente na oração, mas descuidoso.

Mas Cícero, sobre dividir a uis do orador em caso e palavras, diz que do caso é próprio o inuenire, se não também o collocare, e das palavras o eloqui (CIC. Part. 1 3); em outras palavras, ao caso prende a invenção e disposição, que tratam, respectivamente, o que dizer e o lugar em que dizer, e às palavras prende a elocução, que trata o modo como dizer. ${ }^{35}$ Assim, Sêneca, que propugna pela sutileza do caso, repugna ao floreio das palavras, preceitua que o filósofo indague antes da invenção, ou do que dizer, que da elocução, ou do modo como dizer:

Quaere quid scribas, non quemadmodum (115 1; cf. supra n. 29)

Indaga de que escrever, não de como.

Enfim, Cícero diz que o labor da invenção, ou do que dizer, é mais próprio da prudentia, e o da elocução, ou do modo como dizer, mais próprio da eloquentia. ${ }^{36}$ 
Mais que isso, porém, Cícero subordina a eloquentia à prudentia, se não à sapientia ${ }^{37}$ ou scientia (Cıc. Or. 33 118); sapientia e prudentia, porém, são para Cícero partes da filosofia (id. Off. 143 153), de modo que, ao fim e ao cabo, Cícero subordina a eloqüência à filosofia (id. Or. $414-5$ 18; 33 118). Ora, Sêneca, por pensar no filósofo mais que no orador, com mais razão privilegia a ciência ou prudência em detrimento da eloqüência:

Fabianus, vir egregius et vita et scientia et, quod post ista est, eloquentia quoque (40 12)

Fabiano, varão egrégio tanto pela vida como pela ciência como, o que depois disso está, pela eloqüência também;

de maneira que o cuidado com as palavras, mais próprio da eloqüência, sempre se siga ao cuidado com o caso, mais próprio da prudência ou ciência:

Alioquin nocet illis eloquentia, si non rerum cupiditatem facit sed sui (52 14) Por outro lado, é-lhes nociva a eloqüência, se faz o capricho, não dos casos, mas de si mesma;

Si tamen contingere eloquentia non sollicito potest, si aut parata est aut parvo constat, adsit et res pulcherrimas prosequatur: sit talis ut res potius quam se ostendat (75 5)

Se todavia a eloqüência se pode atingir sem solicitude, se ou pronta está ou por pouco se estabelece, apresente-se e siga os mais belos casos; seja tal que aos casos mais que a si ostente;

Vis illum [sc. Fabianum Papirium] adsidere pusillae rei, verbis: ille rerum se magnitudini addixit (100 10)

Queres que ele [=Papírio Fabiano] insista em coisa pequenina: nas palavras; ele dedicou-se à grandeza dos casos. ${ }^{38}$

Até aqui, pois, distingue-se entre filósofo e poeta na medida em que aquele indaga do caso, este das palavras; entre ambos, porém, e o orador distingue-se, em geral, na medida em que aqueles podem tomar uma ou outra coisa, ao passo que o orador deve abraçar ambas. ${ }^{39}$ Se se cuida do caso, pode-se ser agudo (acutus), como o filósofo; se das palavra, elegante (elegans), como o poeta; o agudo e o elegante, porém, são disertos (diserti), mas nem um nem outro eloqüente (eloquens), o que só 
o orador pode ser (cf. Cic. Or. 5 18; 8 25; De or. 112 53-4, 21 94). Em particular, porém, distingue-se entre filósofo e orador na medida em que aquele trata os mores ou maneiras, este os animi ou ânimos. ${ }^{40}$ Daí, porém, filósofo e orador inscrevem-se, respectivamente, no gênero ethikós e no pathetikós, descritos por Cícero (id. Or. 37128 . 38 133). ${ }^{41}$ Ao discurso oratório, pois, cabe irar ou mitigar, incitar inveja ou inspirar favor; ${ }^{42}$ o filosófico, porém, nada tem de irado, nada de invejoso. ${ }^{43}$ Ora, com essa lição concorda a das Epistolas de Sêneca, que diz que o filósofo deve incumbir-se de compor os mores, ${ }^{44}$ mas pode desincumbir-se de excitar os animi. ${ }^{45}$

Em suma, o filósofo, por ocupar-se mais com que dizer, distingue-se, por um lado, do poeta, que se ocupa mais com como dizer (115 1; cf. supra), e, por outro, do orador, que se ocupa mais com quanto dizer:

Recte ergo facies si non audieris istos qui quantum dicant, non quemadmodum quaerunt (40 9)

Corretamente, logo, farás se não ouvires esses que indagam de quanto dizer, não de como.

\section{Invenção dialógica e epistolar}

$\mathrm{Na}$ "Epístola 89", Sêneca expõe a res ou caso filosófico no todo e nas partes. Assim, nomeia e define, primeiro, três partes:

Philosophiae tres partes esse dixerunt et maximi et plurimi auctores: moralem, naturalem, rationalem. Prima componit animum; secunda rerum naturam scrutatur; tertia proprietates verborum exigit et structuram et argumentationes, ne pro vero falsa subrepant (89 9)

Que da filosofia são três as partes: a moral, a natural, a racional, disseram-no tanto o melhor como o mais dos autores. A primeira compõe o ânimo; a segunda escruta a natureza; a terceira trata as propriedades das palavras, a estrutura, as argumentações, para que se não insinue o falso como verdadeiro.

Depois, expõe, subdividindo-as, as mesmas partes: a moral, tripartite (89 14-5); a natural, que se subdivide em corpórea e incorpórea (89 16); a racional, que se subdivide em dialética e retórica (89 17). Enfim, dá primazia ao estudo da parte moral, para ele dirigindo o das outras: 
Haec [sc. partitiones philosophiae], Lucili virorum optime, quominus legas non deterreo, dummodo quidquid legeris ad mores statim referas (89 18)

Não te intimides, Lucílio, melhor dos varões, ao leres isto [=as partições da filosofia], contanto que o que quer que tiveres lido refiras instantaneamente à moral.

Ora, tal disposição tripartite e direção moral, aquela comum aos estóicos, ${ }^{46}$ esta particular de Aristão, ${ }^{47}$ orientam o caso das Epístolas de Sêneca. Tome-se a "Epístola 58". Lá, Sêneca alude, primeiro, questões de gramática, tais como a dificuldade de verter alguns nomes gregos ao latim (58 1-4); daí, tomando o vocábulo tò ón, passa à discussão filosófica, não sem antes esboçar a teoria de Aristóteles sobre gênero e espécie (58 8-15); a discussão filosófica concentra-se, então, na teoria de Platão sobre os seis modos do ente $(58$ 16-22) e na teoria de Heraclito sobre o fluxo das coisas visíveis (58 22-4); daí, passa a aplicar a teoria daqueles filósofos na descrição dos apetites corpóreos do homem (58 25-32), a fim de concluir que, se a parte corpórea da pessoa não ofende a incorpórea, é bem que viva; se não, que é lícito que a pessoa se suicide (58 32-7). Ora, é evidente, em primeiro lugar, o modo como a disposição da epístola obedece à partição do caso filosófico: primeiro, a parte racional, quando se discutem pontos de gramática e da dialética de Aristóteles; depois, a parte natural, subdividida em incorpórea, quando se discute a teoria de Platão sobre idéa e ê̂dos, isto é, sobre insensíveis, e em corpórea, quando se discute a teoria de Heraclito sobre o fluxo dos sensíveis; enfim, a parte moral, quando se discutem os apetites do corpo, a primazia da mens ou animus sobre o corpus, a aceitação da morte. Em segundo lugar, é de reparar a transição entre a discussão filosófica de Platão e Heraclito e a aplicação desta na moral. Pois, então, Sêneca antecipa, por praemunitio, alguma ressalva de Lucílio, dizendo:

'Quid ista' inquis 'mihi subtilitas proderit?' [...] Hoc ego, Lucili, facere soleo: ex omni notione, etiam si a philosophia longissime aversa est, eruere aliquid conor et utile efficere. Quid istis quae modo tractavimus remotius a reformatione morum? quomodo meliorem me facere ideae Platonicae possunt? quid ex istis traham quod cupiditates meas conprimat? (58 25-6)

"Em que aproveitarei”, indagas, "essa sutileza?" [...] Costumo eu, Lucílio, fazer isto: de toda noção, mesmo se de longe é a mais avessa à filosofia, ponho-me a arrancar algo e a fazê[-lo] útil. Que [há] mais remoto da reformação moral que isso que há pouco tratamos? Como me podem fazer melhor as idéias platônicas? Que delas extrairei com que reprima minhas cobiças?. 
Sêneca admite, pois, o estudo das coisas da parte natural da filosofia na medida em que dele se possa extrair algo útil, isto é, algo que se possa empregar na melhoria da vida humana, pelo que a "Epístola 58", sobre atentar na tripartição do caso filosófico, dirige-o ademais para o estudo da moral.

Enfim, Cícero, ao observar a importância do estudo de filosofia para o orador (cf. supra n. 29), refere-se, na verdade, ao estudo de filosofia moral, isto é, ao estudo dos afetos, das virtudes e vícios, como se vê deste passo do Orador:

Nihil enim de religione, nihil de morte, nihil de pietate, nihil de caritate patriae, nihil de bonis rebus aut malis, nihil de virtutibus aut vitiis, nihil de officio, nihil de dolore, nihil de voluptate, nihil de perturbationibus animi et erroribus, quae saepe cadunt in causas et ieiunius aguntur, nihil, inquam, sine ea scientia [sc. philosophia] quam dixi graviter ample copiose dici et explicari potest (Cic. Or. 33 118; cf. 4 16)

Pois nada da religião, nada da morte, nada da piedade, nada da caridade com a pátria, nada das coisas boas ou más, nada das virtudes e vícios, nada do ofício, nada da dor, nada da volúpia, nada das perturbações e errores do ânimo, que amiúde incidem nas causas e mirradamente se tratam, nada, insisto, sem a ciência [=filosofia] que citei, se pode explicar e dizer gravemente, amplamente, copiosamente.

Enfim, confronte-se com o passo sobrecitado de 58 25-6 de Sêneca este outro de Cícero:

Etenim cognitio contemplatioque rerum naturae manca quodam modo atque inchoata sit, si nulla actio consequatur. Ea autem actio in hominum commodis tuendis maxime cernitur; pertinet igitur ad societatem generis humani: ergo haec cognitio anteponenda est. [...] Quibus rebus intellegitur studiis officiisque scientiae praeponenda esse officia iustitiae, quae pertinent ad hominum caritatem, qua nihil homini esse debet antiquius. Atque illi, quorum studia vitaque omnis in rerum cognitione versata est, tamen ab augendis hominum utilitatibus et commodis non recesserunt. [...] Ita illi ipsi doctrinae studiis et sapientiae dediti ad hominum utilitatem suam prudentiam intellegentiamque potissimum conferunt (id. Off. 143153 - 44 156; cf. Fin. 322 73)

Sim, o conhecimento e contemplação das coisas da natureza serão de algum modo mancos e incipientes se nenhuma ação se seguir. A ação, porém, distingue-se principalmente na tutela das comodidades dos homens; logo, pertence à sociedade do gênero humano; logo, é 
para antepor o conhecimento desta [ao das coisas da natureza]. [...] Por tais causas, entende-se que ao estudo e ofício da ciência seja para antepor o ofício da justiça, que pertence à caridade com os homens, a qual deve ser para o homem anterior a tudo. Ademais, aqueles cujos estudos e vida versaram no conhecimento das coisas [da natureza] não se recusaram, todavia, a aumentar o útil e cômodo dos homens. [...] Assim, aqueles mesmos que se dedicaram aos estudos e sabedoria acomodam, em princípio, sua prudência e inteligência à utilidade dos homens.

\section{Elocução dialógica e epistolar}

A elocução divide-se em duas partes, as quais Sêneca preceitua: na eleição das palavras (electio uerborum; cf. 100 5: electa verba) e na composição (compositio; cf. 100 5: compositionem; 1006 compositione; 100 7: compositio; 114 8: compositionis; 114 15: compositionem; ib. compositio) ou juntura das palavras (iunctura uerborum; cf. 114 15: iuncturam). ${ }^{48}$ À eleição das palavras pertencem as palavras metaforizadas (uerba translata), novas (noua) e primevas (prisca), ${ }^{49}$ as quais Sêneca preceitua. Ora, este aconselha que o discurso filosófico eleja, antes de tudo, as palavras remissas (uerba submissa; cf. 38 1: submissiora verba) ou usuais (usitata; cf. 114 13: usitatum); ;0 daí, porém, desaconselha as palavras inusuais, seja as que já não se usam, isto é, os arcaísmos, seja as que ainda não se usam, isto é, os neologismos: ${ }^{51}$

Etiam in oratione quod novum est quaerit et modo antiqua verba atque exoleta revocat ac profert, modo fingit +et ignota ac+ deflectit (114 10)

Ainda na oração indaga do que é novo, e ora revive e profere antigas e obsoletas palavras ora forja até desconhecidas e deforma.

Enfim, ainda faz menção do uso das figuras, admitindo, primeiro, que se usem aquelas que já comparecem no falar cotidiano, tais como comparações, metáforas e parábolas, e, segundo, que se usem sem exagero; ${ }^{52}$ pois tanto usar das figuras mais rebuscadas como abusar das figuras mais comuns são procedimentos caros aos poetas, não ao filósofo: ${ }^{53}$

Invenio tamen [sc. in epistula tua] translationes verborum ut non temerarias ita quae periculum sui fecerint; invenio imagines, quibus si quis nos uti vetat et poetis illas solis iudicat esse concessas, neminem mihi videtur ex 
antiquis legisse, apud quos nondum captabatur plausibilis oratio: illi, qui simpliciter et demonstrandae rei causa eloquebantur, parabolis referti sunt (59 6; cf. 114 1: Quare aliqua aetas fuerit quae translationis iure uteretur inverecunde [sc. quaeris]; 114 10: Pro cultu habetur audax translatio ac frequens)

Encontro todavia [em tua epístola] metaforizações de palavras tais que, mesmo não temerárias, se puseram em perigo; encontro símiles, de que ninguém nos pode vedar o uso, e que não podes conceder que estejam só nos poetas, sem que nada me pareça teres lido dos antigos, entre os quais ainda não ia a oração à cata de aplauso; eles, que falavam com simplicidade e por causa de demonstrar o caso, ${ }^{54}$ são fartos em parábolas (cf.: [Indagas] por que alguma idade houve que reverentemente usasse da justa metáfora; Pelo cultivado [da oração] tem-se metáfora audaciosa e freqüente).

À composição das palavras, por sua vez, ajuntam-se a concordância (concinnitas) e o ritmo (numerus; cf. supra n. 49; Cic. Or. 54 181; 68 228; De or. 343 171, 44 173), os quais Sêneca preceitua. Quanto à composição, este aconselha a oração submissa, desaconselha a immissa (40 6), ou melhor, aconselha a ordem natural (cf. 100 5: contra naturam suam posita), costumeira (cf. 114 7: tam contra consuetudinem omnium posita), desaconselha a ordem inversa (cf. 100 5: inversa [sc. verba]; 114 8: verba transversa), perturbada (cf. 40 6: oratio perturbata; 100 2: perturbatione; 114 15: disturbant), fracionada (cf. 114 1: infracta; 114 15: praefractam; 115 2: fracti), em suma, repudia as circunvoluções da frase (cf. 114 8: ambages compositionis). Quanto ao ritmo, em geral, aconselha o ritmo fluente da conversa, desaconselha o musical dos versos poéticos ou o recitativo das cláusulas oratórias:

Quorundam non est compositio, modulatio est [cf. 114 1: in morem cantici]; adeo blanditur et molliter labitur. Quid de illa loquar in qua verba differuntur et diu expectata vix ad clausulas redeunt? (114 15-6)

A de alguns não é composição, é modulação [cf. à maneira de cântico], tal é a brandura e o mole deslizar. Que falarei daquela em que as palavras são diferidas e, muito esperadas, mal retornam nas cláusulas?. ${ }^{55}$

Em particular, aconselha ao filósofo o ritmo lento, desaconselha o acelerado:

Pedetemptim procedere [sc. debet philosophia] (40 7)

[Deve a filosofia] proceder pé ante pé; 
Ista dicendi celeritas [...] nec satis decora philosophiae (40 7)

Esse célere discurso [...] nem é assaz decoroso para a filosofia; ${ }^{56}$

o discurso veloz convém, se convém, ao orador:

Vix oratori permiserim talem dicendi velocitatem (40 8)

Mal permitira ao orador tão veloz discurso.

Em suma, diz jocoso a Lucílio:

Summa ergo summarum haec erit: tardilocum esse te iubeo (40 14)

Logo, resumo dos resumos será isto: ordeno-te que sejas tardíloquo.

Sêneca considera, ademais, o erro dos que pecam contra a eleição das palavras (cf. 114 14: peccare) ou contra a composição (cf. 114 15: peccetur). Ora, assim como na vida o homem peca por excessivo ou falto, assim na arte (cf. supra); pois se não são as palavras esquisitas e rebuscadas o que se deve eleger, também não as triviais e usitadas, mas as comuns e usuais:

Multi ex alieno saeculo petunt verba, duodecim tabulas loquuntur; Gracchus illis et Crassus et Curio nimis culti et recentes sunt, ad Appium usque et Coruncanium redeunt. Quidam contra, dum nihil nisi tritum et usitatum volunt, in sordes incidunt. Utrumque diverso genere corruptum est, tam mehercules quam nolle nisi splendidis uti ac sonantibus et poeticis, necessaria atque in usu posita vitare. Tam hunc dicam peccare quam illum: alter se plus iusto colit, alter plus iusto neglegit; ille et crura, hic ne alas quidem vellit (114 13-4)

Muitos a outro século pedem as palavras, falam como as doze tábuas; para eles Graco, Crasso, Curião são demasiado cultivados e recentes; até a Ápio e Coruncânio retornam. Alguns, ao contrário, enquanto nada senão o trivial e usitado querem, incidem em sordidezas. Um e outro corromperam-se com gênero diverso, como, por Hércules, com não querer senão do esplendoroso usar e do sonoroso e do poético, com evitar o necessário e posto em uso! Tanto este, diria, como aquele pecam; um mais que o justo é cultivado, o outro mais que o justo é negligenciado; aquele até as pernas, este nem bem as axilas depila;

de maneira que é para eleger aquela palavra que, não sendo a menos comum, também não seja a mais comum: Splendida tamen quamvis sumantur e medio (100 5). 
Quanto à composição das palavras, o erro consiste quer em enriquecer, quer em empobrecer o ritmo. Se se enriquece, obtém-se ritmo, não fluente (cf. 114 15: effluxit), mas flutuante (cf. 114 4: difflueret; 115 18: fluens); se, porém, se empobrece, obtémse ritmo, não calmo, mas entediante:

Nam illa quoque inopia et exilitas minus intentum auditorem habet taedio interruptae tarditatis (40 3)

Pois também aquele desprovido e estreito retém menos a atenção do ouvinte pela interrupção de uma tardança entediante;

de maneira que é para dispor palavras que perfaçam um ritmo, embora sem perturbação, não sem cadência: ${ }^{57}$

Adeo larga est [sc. oratio Fabiani Papiri] et sine perturbatione, non sine cursu tamen veniens (100 2)

Tão larga é [a oração de Papírio Fabiano] e sem perturbação, sem que chegue todavia sem curso;

Aeque stillare illum [sc. philosophum] nolo quam currere; nec extendat aures nec obruat (40 3)

Tanto não quero que [o filósofo] destile como que corra; nem estire os ouvidos [dos ouvintes] nem obstrua;

Disputabat [sc. Fabianus] expedite magis quam concitate (40 12; cf. supra n. 56)

Disputava [Fabiano] expeditamente mais que incitadamente.

Mas a par desses erros, que estão no discursador, outros pode haver no ouvinte; em outras palavras, se uns são erros de emissão, outros há de recepção. Assim, Sêneca corrige o modo como Lucílio ouve Papírio Fabiano. Para Lucílio, este não elege, mas captura palavras:

Electa verba sunt, non captata (100 5)

Foram eleitas as palavras, não capturadas;

nem dispõe, mas apõe palavras, de modo a praticar um ritmo, não profuso, mas difuso: 
Fabianus mihi non effundere videtur orationem sed fundere (100 2)

Não me parece difusa a oração de Fabiano, mas profusa. ${ }^{58}$

Qual, porém, a natureza do erro de Lucílio? Segundo Sêneca, erro de ponto de vista de leitura. Pois o discurso filosófico é tal que se deva mirar à distância, não de perto. ${ }^{59}$ Assim, Lucílio inspeciona as miudezas das partes, quando deveria contemplar o todo da obra. Vistas uma a uma, as palavras não reluzem nem pela forma nem pela disposição; vislumbradas, porém, no conjunto, luzem discretamente:

Idem facit ratio: non late patet, si aspicias; in opere crescit (38 2)

$\mathrm{O}$ mesmo faz o arrazoado: não se patenteia largamente, se inspecionas; cresce na operação;

Praeterea ipso [sc. Fabiano Papirio] dicente non vacasset tibi partes intueri, adeo te summa rapuisset (100 3)

Além disso, se ele próprio [=Papírio Fabiano] discursara, não te vagara a vistoria das partes [do discurso], tanto a soma te arrebatara;

Videbimus quid parum recisum sit, quid parum structum, quid non huius recentis politurae: cum circumspexeris omnia, nullas videbis angustias inanis (100 5)

Veremos o que foi pouco entrecortado, o que pouco estruturado, o que não [é] deste polimento recente; quando o todo contemplares, nenhuma exigüidade inane verás;

Sed totum corpus [sc. orationis Fabiani Papiri], videris quam sit comptum, honestum est (100 8)

Mas o corpo total [da oração de Papírio Fabiano] - vejas quão combinado é - é honrado;

Non erunt sine dubio singula circunspecta nec in se collecta nec omne verbum excitabit ac punget, fateor; exibunt multa nec ferient et interdum otiosa praeterlabetur oratio, sed multum erit in omnibus lucis, sed ingens sine taedio spatium (100 11)

Não estarão contempladas, sem dúvida, as singularidades, nem colacionadas umas com as outras, nem toda palavra incitará ou pun- 
girá, confesso; muitas excederão e não ferirão, e entrementes deslizará ociosa a oração, mas muita luz haverá no todo e ingente espaço sem tédio;

Ceterum verbis abundabat, sine commendatione partium singularum in universum magnificus (100 12)

De resto, sem a recomendação da singularidade das partes, magnífico na unidade [do todo], abundava em palavras.

De certo modo, o sermo é, para quem ouve, algo aparentemente fácil de imitar; para quem fala, porém, é verdadeiramente difícil:

Cum audirem certe illum [sc. Fabianum Papirium], talia mihi videbantur [...], quae adulescentem [...] attolerent et ad imitationem sui evocarent sine desperatione vincendi $(100$ 12)

Como decerto ouvisse a ele [=Papírio Fabiano], pareciam-me [suas palavras] tais [...] que ao adolescente [...] atraíssem e convidassem a imitá-lo, não sem a esperança de [o] vencer. ${ }^{60}$

Em suma, o discurso filosófico deve eleger palavras usuais e dispô-las em ordem costumeira que produza ritmo corrente. Dois erros há, porém: o primeiro, de emissão, quando quem discursa confunde palavras usuais com triviais, disposição costumeira com tediosa, ritmo corrente com frouxo; o segundo, de recepção, quando quem ouve vê de perto o que se devia entrever de longe.

\section{Ação dialógica e epistolar}

A ação (actio) divide-se em duas partes, as quais Sêneca preceitua: em pronunciação (pronuntiatio; cf. 40 2: pronuntiatio), isto é, em vozes (uoces; cf. 75 2: vocem), e em ação (actio) propriamente dita, isto é, em vulto (uultus) e gesto (gestus), expressão facial e corporal (cf. 75 2). ${ }^{61}$ Aqui, porém, Sêneca concentra seus preceitos no discurso oral do filósofo, não no escrito (cf. supra n. 1), de modo que aqueles se apliquem antes ao diálogo que à epístola filosófica. ${ }^{62}$ De modo geral, relega os exageros da ação aos oradores:

Etiam si disputarem, nec supploderem pedem nec manum iactarem nec attollerem vocem, sed ista oratoribus reliquissem (75 2) 
Mesmo se disputasse, eu nem o pé bateria nem projetaria a mão nem a voz dilataria, mas teria relegado isso aos oradores. ${ }^{63}$

Isso, porém, porque as disputas oratórias convêm ao âmbito público - de fato, para falar a muitos, é necessário elevar a voz e contorcer a face e ampliar os gestos -; já a conversa filosófica, por convir ao âmbito particular, não só prescinde, mas repudia aqueles exageros (38 1; cf. supra). ${ }^{64}$

De modo particular, dá ao filósofo a voz e gesto convenientes ao sermo, pois, segundo Cícero, qual o discurso, tal a voz (Cic. Or. 25 85). Ora, se o sermo é submissus (38 1) ou remissus (115 2; cf. supra), assim também a voz que lhe convém. ${ }^{65} \mathrm{O}$ gesto, por sua vez, deve ser comedido. ${ }^{66}$ Do orador, porém, Sêneca, por pensar no filósofo, refere, pejorativamente, não voz alta, mas estrepitosa (cf. 38 1; 40 5):

Plurimum proficit sermo, quia minutatim inrepit animo: disputationes praeparatae et effusae audiente populo plus habent strepitus, minus familiaritatis (38 1)

Muito mais aproveita a conversa, pois que sub-repticiamente se imiscui no ânimo; as disputas preparadas e desferidas em audição pública têm mais estrépito, menos familiaridade;

não gesto amplo, mas impetuoso (cf. 40 4; 46 2; 52 14; 100 3):

Movere vult [sc. haec popularis oratio] turbam et inconsultas aures impetu rapere (40 4)

Quer [esta oração popular] comover a turba e arrebatar com ímpeto ouvidos inconsultos.

Em suma, ao discurso filosófico convêm voz baixa e gestos comedidos e vulto gentil, de modo que o filósofo, ao falar, pareça acanhado e hesitante:

Nihil erat mollius ore Pompei; numquam non coram pluribus rubuit, utique in contionibus. Fabianum, cum in senatum testis esset inductus, erubuisse memini, et hic illum mire pudor decuit (11 4)

Nada era mais maleável que o rosto de Pompeu; sempre, sim, se ruborizava cara à cara com muitos, ainda mais nos comícios. Fabiano, quando conduzido como testemunha ao senado, enrubesceu, lembro-me, e este pudor foi para ele admiravelmente decoroso. 
Ainda de outro modo, porém, pode distinguir-se, pela voz, o discurso filosófico do discurso poético e oratório. Ora, o discurso poético, por prestar-se mais a deleitar, serve antes a ouvir, ao passo que o discurso filosófico, por prestar-se mais a ensinar, serve antes a aprender; ou ainda, o deleitar pára nos ouvidos, o ensinar chega aos ânimos:

Quid aures meas scabis? quid oblectas? (75 7)

Por que coças os meus ouvidos? Por que deleitas?;

Animis scripsit [sc. Fabianus Papirius] ista, non auribus (100 2)

Isso escreveu [Papírio Fabiano] para os ânimos, não para os ouvidos;

Quidam veniunt [sc. in philosophi scholam] ut audiant, non ut discant, sicut in theatrum voluptatis causa ad delectandas aures oratione vel voce vel fabulis ducimur. [...] Sed [sc. id agunt] ut oblectamento aurium perfruantur (108 6)

Alguns chegam [à escola do filósofo] para ouvir, não para aprender, assim como ao teatro somos conduzidos por causa da volúpia, para se deleitarem os ouvidos com a oração ou a voz ou as fábulas. [...] Mas [isso fazem] para fruir a lascívia dos ouvidos.

Já o discurso oratório, por ser de âmbito público, é mais estrepitoso, ao passo que o discurso filosófico, por ser de âmbito familiar, é mais silencioso (cf. supra):

Plurimum proficit sermo, quia minutatim inrepit animo: disputationes praeparatae et effusae audiente populo plus habent strepitus, minus familiaritatis (38 1)

Muito mais aproveita a conversa, pois que sub-repticiamente se imiscui no ânimo; as disputas preparadas e desferidas em audição pública têm mais estrépito, menos familiaridade;

Permittendum erit aliquando iuvenibus sequi impetum animi, tunc autem cum hoc ex impetu facient, cum silentium sibi imperare non poterunt $(52$ 14)

Às vezes será de permitir aos jovens seguir o ímpeto do ânimo, só porém quando fizerem isso com ímpeto, quando não houverem podido impor-se o silêncio. 
Em suma, pode-se dizer que o discurso oratório ou poético exige mais da audição, pelo que é mais ruidoso, ao passo que o discurso filosófico exige mais da intelecção, pelo que é mais íntimo (cf. Cic. De or. 160 255: sermone [...] interiore); em outras palavras, o discurso oratório ou poético é mais sonoroso que significante: Plus sonat quam valet (40 5), ao contrário do filosófico: Plus significans quam loqueris (59 5).

\section{Dissimulação da arte ou arte da dissimulação}

A arte dialógica propõe-nos elaborar o sermo como discurso vizinho à locutio cottidiana. ${ }^{67}$ Mas, de um lado, a locutio cottidiana é mais fácil ou descurada que artificiosa ou elaborada. De fato, é ao não-elaborado (inlaboratum; cf. 40 14: sine ullo tuo labore; 75 1: inlaboratus) e fácil (facile; cf. 40 12: facilitatem; 75 1: facilis) que visa Sêneca; é ao rebuscado (accersitum) e forjado (fictum), bem como ao acurado (accuratum; cf. 75 1: accuratas; ib. accurate; 115 2: curae), que repudia:

Minus tibi accuratas a me epistulas mitti quereris. Quis enim accurate loquitur nisi qui vult putide loqui? Qualis sermo meus esset si una desideremus aut ambularemus, inlaboratus et facilis, tales esse epistulas meas volo, quae nihil habent accersitum nec fictum (75 1)

Queixas-te de que te remeto epístolas menos acuradas. Sim, [pois] quem fala acuradamente, senão o que quer falar putridamente? Qual seria minha conversa, se unidos nos sentássemos ou perambulássemos, não-elaborada e fácil, tais quero que sejam minhas epístolas, que nada têm de rebuscado nem de forjado.

De outro lado, a locutio cottidiana é o que ela mesma é por si, ao passo que o sermo imita o que aquela outra é por arte. De fato, também não é um discurso nãoelaborado o que quer Sêneca:

Haec [sc. verba] autem etiam si aderunt et poterunt sine ullo tuo labore decurrere, tamen temperanda sunt (40 14)

Estas [palavras], porém, mesmo se se houverem apresentado e houverem podido correr sem nenhum labor teu, todavia são para temperar,

pelo que o discurso filosófico demanda muito exercício: Exercitatione opus est cotidiana (40 14). Logo, o Filósofo repudia tanto o discurso sobreornado como a fala 
abjeta: Nec exornassem nec abiecissem (75 2), isto é, tanto o discurso poético como a fala vulgar. É que o sermo, de um lado, se distingue da fala abjeta por esta carecer de arte, de outro, se distingue do discurso sobreornado por este ostentar sua arte. De fato, Sêneca não se levanta contra a eloqüência, mas contra a ostentação desta: ${ }^{68}$

Alioquin nocet illis eloquentia, si non rerum cupiditatem facit sed sui (52 14)

Por outro lado, é-lhes nociva a eloqüência, se faz o capricho, não dos casos, mas de si mesma;

Si tamen contingere eloquentia non sollicito potest, si aut parata est aut parvo constat, adsit [...]: sit talis ut res potius quam se ostendat (75 5)

Se todavia a eloqüência se pode atingir sem solicitude, se ou está pronta ou se estabelece por pouco, apresente-se [...]; seja tal que aos casos mais que a si ostente.

O sermo articula as partes de uma arte geral, pelo que é como o discurso sobreornado, mas dissimula as articulações, pelo que aparenta um discurso abjeto, de maneira que a arte dialógica se revela, ao fim e ao cabo, uma arte de dissimular a arte. ${ }^{69}$ Assim, podem-se rever os preceitos daquela arte do ponto de vista da dissimulação da arte, o que se faz a seguir.

Antes de tudo, o ofício mesmo do filósofo impõe a dissimulação da arte. Pois, assim como o poeta visa, em geral, ao deleitar e, daí, ao belo e feio, assim o filósofo ao ensinar e, daí, ao verdadeiro e falso. ${ }^{70}$ Mas é porque o discurso aparenta fácil e descurado que o discursador aparenta veraz e sincero, pois é quando se entrevê o artifício e premeditação do discurso que se descrê e suspeita do discursador. ${ }^{71}$ Logo, é porque a arte, ou melhor, a ostentação desta conflita com a verdade, a qual é o fim do discurso filosófico, que Sêneca a dissimula:

Quae veritati operam dat oratio incomposita esse debet et simplex: haec popularis nihil habet veri (40 4)

Descomposta deve ser e simples a oração que opera conforme a verdade; esta [oração] popular nada tem de verdadeiro;

Nam, ut ait ille tragicus, 'veritatis simplex oratio est' (49 12)

Pois, como diz o Trágico, "da verdade é simples a oração" [Eur. Ph. 469]; 
Oratio cultus animi est: si circumtonsa est et fucata et manu facta, ostendit illum quoque non esse sincerum et habere aliquid fracti (115 2)

A oração é o cultivo do ânimo; se está circuntosada e tatuada e feita à mão, ostenta que também este não é sincero e possui algo de fraco.

Além disso, também a arte filosófica, por sua vez, impõe a dissimulação da arte, na medida em que lá deve sobressair a ciência à eloqüência (40 12), ${ }^{72}$ bem como os casos às palavras (40 14; 52 14; 59 5; 75 7; 108 6.7), ou a fidedignidade do que se diz ao cuidado com o modo como se diz: ${ }^{73}$

Quaecumque dicit plus habent fiduciae quam curae (115 2)

Cada coisa que diz possui mais fidedignidade que cuidado.

Primazia da invenção, porém, não é o mesmo, bem entendido, que descuido de elocução. Mas o cuidado do discursador é justamente o de evitar que sobressaia o cuidado com a elocução. Logo, pode-se dizer que a negligência da elocução é efeito da diligência efetiva do discursador ${ }^{74}$ pelo que a dissimulação da arte é mesmo a arte do discursador. ${ }^{75}$ Daí, porém, os erros aludidos de emissão ou recepção do sermo, pois quem toma o sermo por descurado ou não-elaborado está na verdade a confundir o que dissimula arte com o que carece de arte, crendo estar a arte presente apenas lá onde está patente. ${ }^{76}$ Mas tal confusão, se não é desejável em quem fala, é-o contudo em quem ouve. Pois se aquilo a que visa a arte dialógica é a aparência de verdade, e se o ouvinte, só quando erra, toma por verdade o que é artifício, logo o erro de recepção deve mesmo ser previsto pelo emissor, de modo que seja erro, não errado, mas acertado. Assim, quando o emissor confunde dissimulação da arte com falta de arte, a emissão é falha; quando, porém, o receptor toma por verdade o que é artifício, a recepção é adequada; ou ainda, no emissor o erro avalia-se como incompreensão da arte dialógica; no receptor, o erro avalia-se como adequação ao propósito do emissor. ${ }^{77}$

Mas como, enfim, o discurso filosófico diligentemente negligencia a elocução? Primeiro, elegendo palavras remissas que se usem mais no sentido próprio que no figurado e dispondo-as em ordem costumeira que produza ritmo fluente. ${ }^{78}$ Depois, destinando-se a ser lido de longe, e não de perto, de modo que as articulações das partes do discurso se ocultem sob a harmonia do todo, ${ }^{79}$ o que obtém afrouxando o que na elocução poderia ser coeso. ${ }^{80}$

Enfim, também o comedimento da ação do filósofo contribui para a dissimulação da arte. Ora, o filósofo, ao falar, deve ser comedido nos gestos e contido na 
voz, afetando acanhamento e hesitação. Primeiro, porque quem ouve toma o discursador acanhado e hesitante por humilde, bem como o seguro e decidido por presunçoso. ${ }^{81}$ Segundo, porque quem fala com segurança denota que o discurso foi preparado, de modo a ostentar mais que a dissimular a arte. ${ }^{82}$

\section{Conclusão}

O discurso adequado ao filósofo deve ser, pelo gênero, conversa, pode ser, pela espécie, epístola, e opõe-se ao discurso poético e ao oratório. Primeiro, porque o discurso filosófico é humilde; o poético, temperado; o oratório, sublime; ou ainda, pelas virtudes e vícios, o discurso filosófico é enxuto ou seco; o poético, elegante ou afetado; o oratório, cheio ou inflado. Segundo, porque, pelo ofício, o discurso filosófico visa ao ensinar; o poético, ao deleitar; o oratório, ao comover. Terceiro, porque, pela arte, o filósofo, de um lado, sutiliza os casos, ao passo que o poeta floreia as palavras; o filósofo, de outro, é ético, quer compor os hábitos, ao passo que o orador é patético, quer excitar os ânimos; em suma, o filósofo ocupa-se com que dizer, o poeta com como dizer, o orador com quanto dizer. Daí define-se a arte adequada ao filósofo. Pela invenção, os casos devem respeitar as três partes da filosofia: a moral, a natural e a racional, e devem privilegiar a primeira, para ela dirigindo os estudos das demais. Pela elocução, as palavras, primeiro, devem elegerse dentre as remissas, pelo que se desaconselham as inusuais, seja os arcaísmos seja os neologismos, e devem empregar-se mais no sentido próprio que no figurado; segundo, devem dispor-se em ordem natural e costumeira que produza ritmo fácil e fluente. Daí, porém, observam-se os erros de emissão e recepção do discurso filosófico. Erra, primeiro, o que, ao falar, confunde elocução remissa com negligente, tomando palavras comuns e usuais por triviais e usitadas, e ritmo fácil e fluente por frouxo e flutuante. Erra, depois, o que, ao ouvir, inspeciona as miudezas das partes do discurso, quando deveria contemplar a magnificência do todo, pois as palavras, vistas uma a uma, não reluzem nem pela forma nem pela disposição, vislumbradas, porém, no todo, luzem discretamente. Pela ação, enfim, a voz do filósofo deve ser baixa; os gestos, comedidos; o vulto, sereno.

A arte dialógica, na medida em que é arte, premedita um discurso, na medida em que é dialógica, premedita um gênero de discurso que é o da conversa. Ora, uma conversa é cheia de caminhos e descaminhos, pelo que é mais fácil e espontânea que elaborada ou premeditada. Logo, o que a arte dialógica nos propõe, ao fim e ao cabo, é a elaboração e premeditação de um discurso vizinho ao não-elaborado 
e improvisado. Antes de tudo, trata-se de respeito ao ofício do filósofo. Pois se este se ocupa com o ensinar e, daí, com o verdadeiro e falso, deve parecer sincero e fidedigno, o que faz pelo discurso, que, então, deve parecer fácil e improvisado. Demais, a negligência da elocução, que na conversa cotidiana é factual, no diálogo ou epístola filosófica é factícia, uma vez que lá consiste na falta, aqui na dissimulação da arte. Daí, aquela negligência é mesmo diligência para o filósofo, ou melhor, a dissimulação da arte é mesmo a arte do filósofo. Daí, porém, observam-se os erros de emissão e recepção do discurso filosófico. Pois erra quem toma por descuido ou defeito o que é cuidado e efeito de elocução. Tal erro, porém, se é conseqüência, em quem fala, da má compreensão da feitura do discurso filosófico, é causa, em quem ouve, da adequada apreensão do efeito do mesmo discurso.

Daí, porém, pode-se prever o paradoxo. Pois o discurso que, ao ser elaborado, ostenta sua arte e, daí, a premeditação do discursador, revela, se não com isto, ao menos nisto, uma verdade. Já o discurso que, apesar de elaborado, dissimula sua arte e, daí, a premeditação do discursador, não é verdade, mas aparenta verdadeiro. Daí, de um lado, o discursador "é" insincero - e nisso de "ser", mais que de "aparentar", é onde há algo de sincero -, de outro, "aparenta" sincero - e nisso de "aparentar" sem "ser" é onde há algo de insincero -. Ora, o que sucede é que lá se revela o modo da práxis, aqui se vela o efeito da poíesis. ${ }^{83}$ Daí, enfim, o paradoxo, pois, no domínio da poíesis, o discurso filosófico revela-se, ao fim e ao cabo, mais eficaz que o poético.

Pois sucede que, no âmbito da poíesis, não há lugar para a expressão da verdade ou sinceridade, senão para o efeito de verossimilhança e fidedignidade. Daí, pois, é a efeito, não a fato que se refere Sêneca, quando descreve o modo como espera ser lido por Lucílio ou o modo como ele mesmo costuma ler as epístolas do amigo:

Si quando intervenerunt epistulae tuae, tecum esse mihi videor et sic adficior animo tamquam tibi non rescribam sed respondeam $(672)$

Se alguma vez sobrevieram tuas epístolas, pareço eu estar contigo e de tal modo sou afetado no ânimo que a ti responda, não escrevendo, mas falando;

Quod frequenter mihi scribis gratias ago; nam quo uno modo potes te mihi ostendis. Numquam epistulam tuam accipio ut non protinus una simus (40 1) Porque freqüentemente me escreves, agradeço, pois do único modo que podes te ostentas a mim. Nunca recebo espítola tua sem que unidos não estejamos prontamente. 
Tal é o modo de escrever uma epístola, o de quem, mais que escrever, se mostra ao outro; tal é o modo de ler uma epístola, o de quem, mais que ler, vê o outro; como o mesmo Sêneca diz:

Si fieri posset, quid sentiam ostendere quam loqui mallem (75 2)

Se se pudesse fazer, preferiria ostentar o que sinto a falar.

Mas que Sêneca se refere a efeito, não a fato, é o que se comprova pelo cotejo dos textos sobrecitados do Filósofo com outro de Quintiliano em que se descreve o efeito a que se chama, em grego, enárgeia, em latim, inlustratio ou euidentia ou repraesentatio (cf. QUINT. 62 32; 83 62): 84

Insequetur enárgeia [...], quae non tam dicere uidetur quam ostendere, et adfectus non aliter quam si rebus ipsis intersimus sequentur (id. 62 32)

Seguir-se-á a enárgeia [...], que parece não tanto dizer como ostentar, e os afetos seguir-se-ão não diferentemente do que se estivéssemos em meio às próprias coisas. ${ }^{85}$

Confrontem-se as palavras mesmas de um e outro: de Sêneca, ostendere quam loqui (75 2), de Quintiliano, non tam dicere quam ostendere; daquele, adficior (67 2), deste, adfectus. ${ }^{86}$

Enfim, Sêneca descreve o paroxismo de tal efeito, ao afirmar que o poder de representação visual da epístola é ainda maior que o de uma pintura:

Quod frequenter mihi scribis gratias ago; nam quo uno modo potes te mihi ostendis. Numquam epistulam tuam accipio ut non protinus una simus. Si imagines nobis amicorum absentium iucundae sunt, quae memoriam renovant et desiderium [absentiae] falso atque inani solacio levant, quanto iucundiores sunt litterae, quae vera amici absentis vestigia, veras notas adferunt? Nam quod in conspectu dulcissimum est, id amici manus epistulae inpressa praestat, agnoscere (40 1)

Porque freqüentemente me escreves, agradeço, pois do único modo que podes te ostentas a mim. Nunca recebo espítola tua sem que unidos não estejamos prontamente. Se as imagens dos amigos ausentes nos rejubilam, as quais renovam a memória e aliviam a saudade com falso e inane consolo, quão mais nos rejubilam as letras, as quais referem os vestígios verdadeiros, as notas verdadei- 
ras do amigo ausente? Pois ao que, ao conspecto [do amigo], é o mais doce, a isso a mão do amigo impressa na epístola se presta: ao reconhecer.

\section{Notas}

* Professor de Língua e Literatura Latina do Curso de Graduação da FFLCH-USP e Doutorando em Latim do Programa de Pós-Graduação em Letras Clássicas da FFLCHUSP.

1 Discurso e escrito filosófico exemplar são, para Sêneca, os de Papírio Fabiano. Assim, na "Epístola 52", após breve caracterização dos discursos do Filósofo (cf. 52 11: Disserebat [...] Fabianus), promete Sêneca exame mais particular e detido daqueles discursos (52 15); tal exame, porém, parece estar já na "Epístola 40 " (cf. 40 12: Fabianus [...] disputabat), ao passo que na "Epístola 100" há o exame dos escritos, e não dos discursos de Papírio Fabiano (cf. 100 1: Fabiani Papiri libros; 100 3: ad manum relata).

2 Assim também Cícero: Itaque sermo potius quam oratio dicitur [sc. oratio philosophorum] (CIc. Or. 19 64; cf. Off. 137 134) "E assim [a oração dos filósofos] diz-se antes conversa que oração[, isto é, antes discurso dialógico que discurso oratório]”.

3 Assim também Cícero: In iis sermonibus, qui diálogoi dicuntur (Cic. Or. 44 151) "Naquelas conversas (sermonibus) que se dizem diálogoi"; Vt est consuetudo dialogorum, cum sermo esset institutus (id. Br. 60 218) "Como é o costume dos diálogos (dialogorum), já que se instituíra a conversa (sermo)”.

4 Assim também Cícero: Sermo in circulis, disputationibus, congressionibus familiarium versetur (Cic. Off. 137 132) "Verse nos círculos, disputas, congressos familiares a conversa".

5 Assim também Cícero:

Et quoniam magna vis orationis est eaque duplex, altera contentionis, altera sermonis, contentio disceptationibus tribuatur iudiciorum, contionum, senatus, sermo in circulis, disputationibus, congressionibus familiarium versetur (CIC. Off. 137 132)

E já que há o vigor oratório, e este é duplo, um da contenda, outro da conversa, atribua-se às discussões dos julgamentos, dos comícios, do senado a contenda; verse nos círculos, disputas, congressos familiares a conversa;

Neque minus haec tamen tua gravissimi sermonis lenitas, quam illa summa vis et contentio probatur: multique oratores fuerunt, ut illum Scipionem audimus et Laelium, qui omnia sermone conficerent paulo interiore, numquam, ut Ser. Galba, lateribus aut clamore contenderent (id. De or. 160 255)

E esta tua leveza de conversa grave, todavia, não se aprova menos que aquele sumo vigor e contenda, e muitos oradores houve, dês que ouvimos um 
Cipião e um Lélio, que tudo perfizessem com conversa pouco mais íntima, nunca, como Sér. Galba, contendessem a braços ou clamor.

Cf. id. De or. 345 177, 53 203; Her. 323.

6 Assim também Cícero: Tamen horum [sc. philosophorum] oratio neque nervos neque aculeos oratorios ac forensis habet (CIc. Or. 19 62) "Todavia a oração destes [=filósofos] nem os nervos nem os aguilhões oratórios e forenses tem".

7 Assim também Horácio, que aos versos dos poetas opõe tanto o sermo epistolar:

Nunc itaque et versus et cetera ludicra pono;

quid verum atque decens, curo et rogo et omnis in hoc sum;

condo et compono quae mox depromere possim (Hor. Ep. 11 10; cf. Ps. Acr. Ep.

11 7.13.17)

Agora, então, tanto os versos como os restantes lazeres deponho;

o verdadeiro e decente é o que procuro e rogo, e todo nisso estou;

construo e componho o que logo possa sacar;

Ipse ego, qui nullos me adfirmo scribere versus (Hor. Ep. 21111 )

Eu próprio, que afirmo nenhum verso escrever,

como o satírico:

Primum ego me illorum dederim quibus esse poetas

excerpam numero: neque enim concludere versum

dixeris esse satis; neque si qui scribat uti nos

sermoni propiora, putes hunc esse poetam (id. S. 14 39-42)

Primeiro, eu do número daqueles a que concedi serem poetas

me excluo, pois nem completar o verso

dirás que é suficiente, nem, se alguém escrever como nós

algo mais próximo à conversa, penses que ele é poeta.

8 Assim também Horácio, que ao sermo opõe as espécies poéticas do carmen e dos iambi, isto é, a ode e o epodo:

Denique non omnes eadem mirantur amantque:

carmine tu gaudes, hic delectatur iambis,

ille Bioneis sermonibus et sale nigro (HoR. Ep. 2 2 58-60) 
Daí, não todos admiram e amam o mesmo;

tu te regozijas com o carme, este se deleita com os iambos,

aquele com as conversas de Bião e o sal negro.

9 Horácio designa suas epístolas tanto pela palavra específica epistula (Hor. Ep. 222 2) como pela genérica sermo (id. Ep. 214 ), e assim como Sêneca qualifica sermo por familiaris (cf. supra), assim Cícero equipara epistula a sermo familiaris:

Itaque propter hanc dubitationem meam brevior haec ipsa epistola est, quod, cum incertus essem, ubi esses, nolebam illum nostrum familiarem sermonem in alienas manus devenire (CIC. Att. 19 1)

E assim, por esta minha dúvida, é mais breve esta mesma epístola, porque, como não estivesse certo do lugar onde estavas, não queria que a nossa conversa familiar chegasse a mãos alheias.

Mas o Orador ainda qualifica o sermo epistolar tanto por quotidianus:

Quanti enim me faceres cum ex sermonibus quotidianis meis, tum ex epistolis etiam tuis potuit cognoscere (id. Fam. 13 19 3; cf. 921 1; Her. 3 23: Sermo est oratio [...] finitima cottidianae locutioni; 4 17: in sermone et consuetudine cottidiana)

Tanto, sim, de minhas conversas cotidianas como até mais de tuas epístolas pôde conhecer quanto me prezavas (cf.: Conversa é oração [...] confinante com a locução cotidiana; Em conversa e costume cotidiano),

como por plebeius: Verumtamen quid tibi ego in epistolis videor? nonne plebeio sermone agere tecum? (Cic. Fam. 921 1) "Em verdade, que te pareço eu nas epístolas? Não é que [pareço] tratar contigo em conversa plebéia?”. Seja como for, a epístola, espécie do sermo, pode-se opor ao discurso deliberativo e ao judicial, espécies da contentio: Quid enim simile habet epistola aut iudicio aut contioni? (id. Fam. 921 1) "Que semelhança, pois, tem a epístola quer com o julgamento quer com o comício?”.

10 Cic. Or. 20 68: Seiunctus igitur orator a philosophorum eloquentia, a sophistarum, ab historicorum, a poetarum explicandus est nobis qualis futurus sit "Desvinculado, logo, o orador da eloqüência dos filósofos, da dos sofistas, da dos historiadores, da dos poetas, é para explicarmos qual há de ser"; cf. 1961.

11 Cic. Or. 19 62: Quamquam enim et philsophi quidam ornate locuti sunt [...], tamen horum oratio neque nervos neque aculeos oratorios ac forensis habet "Se bem que até alguns filósofos, sim, tenham falado ornadamente [...], todavia a oração destes nem os nervos nem os aguilhões oratórios e forenses tem".

12 Cic. Or. 19 65: Sophistarum [...] magis distinguenda similitudo videtur "Parece que é mais para distinguir a semelhança dos sofistas”. 
13 Cic. Or. 20 66: Huic generi [sc. sophistarum] historia finitima est "Com este gênero [dos sofistas] é confinante a história”; cf. 11 37; 61207.

14 Cic. Or. 20 66: Ab his [sc. sophistis] non multo secus quam a poetis haec eloquentia quam quaerimus sevocanda est "Destes [=sofistas] não menos que dos poetas é para revocar a eloqüência que requeremos".

15 Também Cícero qualifica o discurso do filósofo, isto é, o sermo, por humilis, por demissus, por tenuis (Cic. Or. 58 196: demisso atque humili sermone; De or. 113 57: tenui [...] sermone; cf. Her. 3 23: Sermo est oratio remissa; HoR. Ep. 2 1 250-1: sermones [...] / repentis per humum), e, ao tratar o discurso humilis (Cic. Or. 2375 - 26 90), equipara todos aqueles adjetivos (id. Or. 23 76: summissus est et humilis; De or. 253 212: lenis [...] atque summissa; Br. 92 317: remissus et lenis; cf. Or. 24 81: tenuis, ib.: demissior, 24 82: summissus, 26 90: summissi, 29 100: humilia subtiliter, 29 101: parva summisse). Ademais, opõe o discurso do orador, isto é, a contentio, ora ao summissus, ora ao remissus, ora ao lenis (id. De or. 355 212: alias contentius, alias summissius; cf. 160 255; Or. 25 85), o que também se vê do passo 1008 de Sêneca, em que o discurso oratório (cf. ib.: oratorius vigor) se opõe ao discurso humilis ou placidus, e do passo 402 , em que o discurso oratório (cf. ib.: oratori) se opõe ao lenis. Já neste passo: Non enim semper fortis oratio quaeritur, sed saepe placida, summissa, lenis (id. De or. 243 183) "Sim, nem sempre se requer a oração forte, mas amiúde a plácida, remissa, leve”, sobre equiparar três dos adjetivos empregados por Sêneca, Cícero opõe-nos ao adjetivo fortis, o que também se vê do passo 11415 de Sêneca. Enfim, Sêneca qualifica o discurso oratório por immissus (40 6).

16 Cf. Her. 4 15: Est autem cauendum ne, dum haec genera consectemur, in finituma et propinqua uitia ueniamus "É, porém, para acautelar-nos de, enquanto esses gêneros perseguimos, achegar-nos dos vícios confins e próximos”.

17 Cícero designa o vício do pressus por inopia et ieiunitas, se não por exile e aridum genus sermonis (Cic. De or. 238 159), e qualifica o do amplus por inflatus et corruptus:

Sed cavenda est presso illi oratori inopia et ieiunitas, amplo autem inflatum et corruptum orationis genus (id. Br. 55 202)

Mas é para precaver-se aquele orador compresso do desprovido e mirrado; o amplo [orador], porém, do gênero de oração inflado e corrupto.

Já Horácio, ao pensar no vício próprio de cada gênero (Hor. AP 31), entende que o do gênero leve é carecer dos nervos oratórios (cf. Cic. Or. 19 62: nervos [...] oratorios; De or. 352 199: nervis), o do grande inturgescer, o do humilde serpear pelo chão:

\section{[...] Sectantem levia nervi}

deficiunt animique; professus grandia turget;

serpit humi tutus nimium timidusque procellae (HoR. AP 26-8) 
[...] Ao que segue o leve nervos

e ânimos faltam; o que promete o grande é túrgido;

serpeia humilde o que é tutelado demais e teme a procela.

18 Cic. Opt. 1 2: Oratorum autem si quis ita numerat plura genera, ut alios grandis aut gravis aut copiosos, alios tenuis aut subtilis aut brevis, alios eis interiectos et tamquam medios putet [...] "Se, porém, dos oradores alguém enumera muitos gêneros, de modo que a uns repute grandes ou graves ou copiosos, a outros tênues ou sutis ou breves, a outros interpostos a esses e como que médios [...]”.

19 Cic. Or. 6 22: Horum singulorum generum quicunque vim in singulis consecuti sunt "Cada qual perseguiu em cada um o vigor de cada um destes gêneros"; Hor. AP 38 9: Sumite materiam vestris, qui scribitis, aequam / viribus "Assumi matéria vós, que escreveis, equivalente / aos vigores [vossos]".

20 Cic. Or. 28 97: Tertius est ille amplus copiosus, gravis ornatus, in quo profecto vis maxima est "O terceiro [orador] é o amplo [e] copioso, grave [e] ornado, no qual de fato é máximo o vigor" (cf. 21 69); 19 61: Dicendi autem, id est eloquendi, maxima vis soli huic [sc. oratori] conceditur "Do discurso, porém, isto é, da elocução concede-se o máximo vigor a este [=orador] só”.

21 Cic. Or. 23 76: Etiam si illis maximis viribus careat [sc. orationis subtilitas] "Mesmo se daqueles máximos vigores carece [a sutileza da oração]"; cf. De or. 160 255; 352199.

22 Cic. Or. 21 69: Sed quot officia oratoris, tot sunt genera dicendi "Mas quantos são os ofícios do orador, tantos os gêneros do discurso".

23 Cic. Or. 21 69: Subtile in probando, modicum in delectando, vehemens in flectendo "Sutil no provar, módico no deleitar, veemente no dobrar [os ânimos]"; De or. 229 128-9: Tres sunt res [...]: una conciliandorum hominum, altera docendorum, tertia concitandorum. Harum trium partium prima lenitatem orationis, secunda acumen, tertia vim desiderat "Três são as coisas [...]: uma, de conciliar os homens; outra, de ensinar; terceira, de incitar. Destas três partes a primeira deseja a leveza da oração, a segunda a agudeza, a terceira o vigor"; Or. 5 20: Nam et grandiloqui [...] fuerunt [...], ad permovendos et convertendos animos instructi et parati [...], et contra tenues [...], omnia docentes "Pois tanto grandiloqüentes [...] houve [...], instruídos e preparados para comover e converter os ânimos [...], como, ao contrário, tênues [houve] [...], a ensinar tudo".

24 Cic. De or. 253 215: Qua re qui aut breviter aut summisse dicunt, docere iudicem possunt, commovere non possunt "Por tal causa, os que ou abreviadamente ou remissamente discursam podem ensinar o juiz, não podem comover”.

25 Cic. Or. 19 63: Loquuntur cum doctis, quorum sedare animos malunt quam incitare, et de rebus placatis ac minime turbulentis docendi causa non capiendi loquuntur "Falam [os filósofos] com doutos, cujos ânimos preferem assentar a incitar, e de coisas plácidas e menos turbulentas falam com o fim de ensinar, não de cativar".

26 Cícero prende o deleitar ao sofista também, na medida, porém, em que o mesmo gênero dos sofistas se prende ao dos poetas (cf. Cic. Or. 20 66): 
Cum sit his [sc. sophistis] propositum non perturbare animos, sed placare potius nec tam persuadere quam delectare [...] (Cic. Or. 19 65)

Como o propósito destes [sofistas] é, não perturbar os ânimos, mas antes aplacar, e não tanto persuadir quanto deleitar [...].

27 Cf. Crc. Or. 19 63: docendi causa; 24 82: docendi causa; 25 84: aucupium delectationis; HOR. AP 333.

28 Non nulli eorum [sc. poetarum] voluntati vocibus magis quam rebus inserviunt (CIC. Or. 20 68) "Não poucos deles [= poetas] servem à vontade, às vozes, mais que aos casos". Daí, porém, também no discurso modicus diz Cícero que incidem todos os ornamentos das palavras (id. Or. 27 95).

29 Quod in ea [sc. cognitione rerum] solum illi [sc. philosophi] voluerint elaborare (CIC. De or. 112 54) "Porque nele [=conhecimento dos casos] tão-só aqueles [=filósofos] quiseram laborar”. Ao assinalar a importância que tem o conhecimento de filosofia para o orador (id. Or. 33 118), diz Cícero que aquela ciência é só o que pode ensinar o orador a pensar primeiro o caso e depois as palavras:

Volo enim prius habeat orator rem de qua dicat [...] quam cogitet quibus verbis quidque dicat (id. Or. 34 119; cf. 16 51: Vbi [sc. in philosophia] res spectatur, non verba penduntur)

Quero, sim, tenha o orador o caso de que discurse [...] primeiro que cogite as palavras com que de cada coisa discurse (cf.: Onde [=na filosofia] se respeita o caso, não se ponderam as palavras).

Horácio, por sua vez, aconselha a quem quer escrever bem que inquira o caso dos textos socráticos:

Rem tibi Socraticae poterunt ostendere chartae (HoR. AP 310)

Os códices socráticos poderão ostentar-te os casos.

Daí, porém, também o discursador humilde diz Cícero que é como quem elabora mais o caso que as palavras: [...] de re hominis magis quam de verbis laborantis (CIC. Or. 23 77) "[...] de homem que labora no caso mais que nas palavras".

30 Assim como Cícero distingue entre o filósofo e o sofista por aquele ater-se ao caso, este às palavras:

A re saepe discedunt [sc. sophistae], [...] verba altius transferunt (CIc. Or. 19 65; cf. 12 37-8)

Distanciam-se [os sofistas] amiúde do caso, [...] metaforizam mais amplamente as palavras, 
assim também Sêneca distingue entre o filósofo e o dialético (cf. 45 13: litem cum dialecticis), pois tanto este como o sofista cuidam tão-só de distinguir as coisas pelas palavras, descuidando de o fazer também pelo caso:

Nectimus nodos et ambiguam significationem verbis inligamus ac deinde dissolvimus [...]. Tota illo mente pergendum est ubi provideri debet ne res nos, non verba decipiant. Quid mihi vocum similitudines distinguis, quibus nemo umquam nisi dum disputat captus est? Res fallunt: illas discerne (45 5-6; cf. 49 6)

Atamos os nós, e o significado ambíguo enleamos com palavras e depois resolvemos [...]. É para progredir inteiramente lá onde nos devemos precaver de que a nós os casos mais que as palavras enganem. Por que me distingues as semelhanças das vozes pelas quais ninguém jamais é enganado senão quando disputa? Falaciosos são os casos; discerne-os a eles.

Em outras palavras, tanto o sofista como o dialético são, para Cícero bem como para Sêneca, cauillatores ou ardilosos (cf. 45 5: verborum cavillatio; 111 1: cavillationes).

31 É o que diz, na verdade, do discursador humilde:

Verba etiam verbis quasi coagmentare neglegat. Habet enim ille [sc. summisus et humilis] [...] quod indicet [...] neglegentiam de re hominis magis quam de verbis laborantis (Cic. Or. 23 77)

Negligencia como que o ajuntamento de palavra com palavra. Tem, sim, aquele [orador remisso e humilde] [...] o que indique [...] negligência de homem que labora no caso mais que nas palavras.

32 É o que diz, na verdade, do discursador humilde: Sed quaedam etiam neglegentia est diligens (CIc. Or. 23 78) "Mas é diligente ainda alguma negligência".

33 É o que diz, na verdade, do discursador humilde (cf. Cic. Or. 23 77: non ingratam neglegentiam).

34 Também o termo sensus ou sentido, equiparável a res, Sêneca qualifica por magnus ou magnificus (cf. 100 5: sensus [...] magnificos; 114 8: sensus [...] magni).

35 Assim se definem as três partes da uis do orador pelas três coisas que são para este reparar:

Quoniam tria videnda sunt oratori: quid dicat et quo quidque loco et quo modo (Cic. Or. 14 43; cf. 16 51; Inu. 17 9; Her. 12 3)

Já que três coisas são para o orador ver: que dizer e em que lugar cada coisa [dizer] e de que modo [dizer].

36 Cic. Or. 14 44: Nam et invenire et iudicare quid dicas magna illa quidem sunt [...], sed propria magis prudentiae quam eloquentiae "Pois tanto inventariar, como julgar o que 
dizer, bem são coisas grandes [...], mas mais próprias da prudência que da eloqüência" (cf. 3 13; 5 18; 42 145; 49 162; 3 13); 17 55: Quo modo autem dicatur, id est in duobus, in agendo et in eloquendo "O modo, porém, como dizer está em duas coisas: na ação e na elocução".

37 Cic. Or. 21 70: Sed est eloquentiae sicut reliquarum rerum fundamentum sapientia "Mas da eloqüência assim como das restantes coisas o fundamento é a sabedoria”; Inu. 1 1: Ac me quidem diu cogitantem ratio ipsa in hanc potissimum sententiam ducit, ut existimem sapientiam sine eloquentia parum prodesse civitatibus, eloquentiam vero sine sapientia nimium obesse plerumque, prodesse nunquam "A mim, ademais, com diuturna cogitação, a própria razão bem conduz, em princípio, a este sentimento: à estimativa de que a sabedoria sem eloqüência pouco aproveita aos cidadãos; a eloqüência sem sabedoria, em verdade, o mais das vezes obsta demasiado, nunca aproveita”; De or. 21 5: Neminem eloquentia non modo sine dicendi doctrina, sed ne sine omni quidem sapientia florere umquam et praestare potuisse "Ninguém jamais pôde florescer e prevalecer em eloqüência não apenas sem doutrina do discurso mas sequer sem a sabedoria toda”.

38 Assim também Horácio: Verbaque provisam rem non invita sequentur (Hor. AP 311) "E as palavras seguirão, não involuntárias, o caso previsto”.

39 Cic. Or. 21 72: Philosophi solent in officiis tractare [...], grammatici in poetis, eloquentes in omni et genere et parte causarum "Os filósofos soem tratar nos ofícios [...], os gramáticos nos poetas, os eloqüentes em todo gênero e toda parte das causas”.

40 Daí, também do discurso amplo é próprio o tratamento dos ânimos, já que este é, na verdade, o mesmo que o ofício do comover: Huius eloquentiae [sc. amplae] est tractare animos, huius omni modo permouere (Cıc. Or. 28 97) "Desta eloqüência [ampla] é o tratar os ânimos, desta o comover de todo modo”.

41 Cf. Cic. Or. 37 128: Alterum est, quod Graeci ethikòn vocant, ad naturas et ad mores et ad omnem vitae consuetudinem accomodatum; alterum, quod idem pathetikòn nominant, quo perturbantur animi et concitantur, in quo uno regnat oratio "Um gênero, que os gregos chamam ethikós, é acomodado às naturezas, às maneiras, ao costume todo da vida; o outro, que os mesmos nomeiam como pathetikós, [é] o com que se perturbam e incitam os ânimos, único em que reina a oração".

42 Cic. Or. 38 131: Sed est faciendum etiam [sc. oratori] ut irascatur iudex mitigetur, invideat faveat, contemnat admiretur, oderit diligat, cupiat fastidiat, speret metuat, laetetur doleat "Mas é para [o orador] fazer ainda que se ire, se mitigue o juiz; inveje, favoreça; desestime, admire; odeie, se deslumbre; cobice, se enfastie; espere, tema; se alegre, se doa”.

43 Cic. Or. 19 64: Nihil iratum habet [sc. oratio philosophorum], nihil invidum, nihil atrox, nihil miserabile, nihil astutum "Nada de irado tem [a oração dos filósofos], nada de invejoso, nada de atroz, nada de comiserante, nada de astuto".

44100 2: Mores ille [sc. Fabianus Papirius], non verba composuit "Ele [=Papírio Fabiano] compôs as maneiras, não as palavras”.

4540 5: Lenienda sunt quae me exterrent, conpescenda quae inritant, discutienda quae fallunt, inhibenda luxuria, corripienda avaritia "É para aliviar o que me aterra, para ser parco 
do que irrita, para sacudir o que falseia, para inibir a luxúria, corrigir a avareza"; 100 10: 'Desideres' inquis 'contra vitia aliquid aspere dici, contra pericula animose, contra fortunam superbe, contra ambitionem contumeliose. Volo luxuriam obiurgari, libidinem traduci, inpotentiam frangi' "'Desejas', insistes, 'que contra os vícios se diga algo asperamente; contra os perigos, animosamente; contra a fortuna, soberbamente; contra a ambição, contumazmente. Quero que ao luxurioso se objete, o libidinoso se desconsidere, o prepotente se enfraqueça'”.

4688 24: 'Quemadmodum' inquit [sc. Posidonius] 'est aliqua pars philosophiae naturalis, est aliqua moralis, est aliqua rationalis [...]' “'Assim como', insiste [Posidônio], 'uma parte da filosofia é natural, uma é moral, uma é racional [...]”".

4789 13: Ariston Chius non tantum supervacuas esse dixit naturalem et rationalem sed etiam contrarias; moralem quoque, quam solam reliquerat, circumcidit "Aristão de Quio disse ser não apenas supérfluas [as partes] natural e racional, mas ainda contrárias; também a moral, a só que reconhecera, entrecortou”.

48 Cic. Or. 59 201: Est enim in utroque [sc. oratione poematibusque] et materia et tractatio: materia in verbis, tractatio in conlocatione verborum "Há, sim, num e noutro [=na oração e nos poemas, isto é, na prosa e no verso] tanto matéria como tratamento: matéria nas palavras, tratamento na colocação das palavras"; De or. 337 149: Omnis igitur oratio conficitur ex verbis; quorum primum nobis ratio simpliciter videnda est, deinde coniuncte. Nam est quidam ornatus orationis, qui ex singulis verbis est; alius, qui ex continuatis [coniunctis] constat "Logo, toda oração constitui-se de palavras, das quais é para vermos primeiro a relação simples, depois a conjunta. Pois há um ornato da oração que está na singularidade das palavras, outro que consta da continuação [e] conjunção"; Hor. AP 46-8.

49 Cic. Or. 60 201: Ternae autem sunt utriusque partes: verborum translatum, novum, priscum [...]; conlocationis autem eae quas diximus, compositio, concinnitas, numerus "Ternas, porém, são as partes de umas e outra: das palavras, a metafórica, a nova, a primeva [...]; da colocação [das palavras], porém, o que dissemos: a composição, a concordância, o ritmo"; De or. 338 152: Tria sunt igitur in verbo simplici, quae orator adferat ad inlustrandam atque exornandam orationem: aut inusitatum verbum aut novatum aut translatum "Três coisas, logo, estão na simples palavra, as quais o orador confere à ilustração e ornamentação da oração: ou a palavra inusitada ou a inovada ou a metaforizada"; 343 170: Ita fit, ut omnis singulorum verborum virtus atque laus tribus exsistat ex rebus: si aut vetustum verbum sit [...]; aut factum [...]; aut translatum "Assim, é fato que toda virtude e louvor das palavras simples consistam em casos, se for a palavra ou vetusta [...], ou feita [...], ou metaforizada"; Hor. AP 48-59.

50 É o que Cícero diz que faz nas epístolas: Epistolas vero quotidianis verbis texere solemus (Cic. Fam. 921 1) "Nas epístolas, em verdade, soemos entretecer palavras cotidianas". É também o que aconselha ao discursador tênue: Vtaturque [sc. ille tenuis orator] verbis quam usitatissimis (id. Or. 25 85) "E use [aquele orador tênue], quanto puder, das mais usitadas palavras”. A Retórica a Herênio define os uerba usitata como próprios do sermo: Vsitata sunt ea quae uersantur in sermone (Her. 4 18) "Usitadas são aquelas que se versam na conversa”. 
51 Cic. Or. 24 81: Ergo ille tenuis orator, modo sit elegans, nec in faciendis verbis erit audax [...] et parcus in priscis "Logo, aquele orador tênue, desde que elegante, não será audaz no feitio das palavras [...] e [será] nas [palavras] primevas parcimonioso”.

52 Cic. Or. 24 81: In transferendis [sc. verbis] verecundus [sc. erit ille tenuis orator] [...]; ea translatione fortasse crebrior, qua frequentissime sermo omnis utitur non modo urbanorum, sed etiam rusticorum "Na metaforização das palavras [será] reverente [aquele orador tênue] [...]; [será] mais assíduo, acaso, à metáfora de que mui freqüentemente usa toda conversa, não só a urbana, mas ainda a rústica”; 25 85: Vtaturque [sc. ille tenuis orator] [...] translationibus quam mollissimis "E use [aquele orador tênue] [...], quanto puder, das mais maleáveis metáforas".

53 Tal se aplica, na verdade, a toda a eleição de palavras:

Sed in utroque frequentiores sunt et liberiores poetae; nam et transferunt verba cum crebrius tum etiam audacius et priscis libentius utuntur et liberius novis (CIC. Or. 60 202; cf. Her. 4 15)

Mas numa e noutra [parte] são mais freqüentes e mais livres os poetas, pois tanto metaforizam palavras, se já mais assiduamente, ainda mais audazmente, como mais lépidos usam das primevas, e das novas, mais livres.

Demais, o abuso das figuras é próprio do discurso módico ou temperado: In idem genus orationis - loquor enim de illa modica ac temperata - verborum cadunt lumina omnia (Cır. Or. 27 95; cf. 27 92-4) "No mesmo gênero de oração - falo, sim, daquela módica e temperada - incidem todas as luzes".

54 Cf. Cic. Or. 19 63: docendi causa non capiendi "por causa de ensinar, não de cativar"; 24 82: docendi causa [...], non ludendi "por causa do ensino [...], não do lúdico".

55 Cf. Cic. Or. 68 227: Non quin idem sint numeri non modo oratorum et poetarum verum omnino loquentium, [...] sed ordo pedum facit, ut id quod pronuntiatur aut orationis aut poematis simile videatur "Não que não sejam os mesmos os ritmos não só dos oradores e poetas mas de todos os falantes, [...] mas a ordem dos pés faz que o que se pronuncia pareça semelhante ou a oração ou a poema” (cf. 59201 - 60 202). Dos oradores Cícero também alude aos asiáticos, por parecerem mais cantar que discursar: Cum vero inclinata ululantique voce more Asiatico canere coepisset [...] (id. Or. 8 27) "Como, em verdade, tivesse começado à maneira asiática, com voz flexionada e ululante [...]”. É a tal maneira asiática que Sêneca talvez se refira quando diz: in morem cantici (114 1) "à maneira de cântico".

56 Quanto ao vocabulário, confrontem-se os termos celeritas (40 7) e concitate (40 12) de Sêneca com a expressão oratione celeri et concitata de Cícero (Cic. De or. 21 88).

57 Cic. Or. 23 77: Solutum quiddam sit nec vagum tamen, ut ingredi libere, non ut licenter videatur errare "Seja algo solto, não vago todavia, de modo que pareça progredir livremente, e não errar licenciosamente".

58 Sobre a oposição entre os termos fundere e effundere, confiram-se os passos de 381 (disputationes [...] effusae), 402 (effundit), 1001 (effundi), 10010 (Non est violenta [sc. 
oratio Fabiani Papiri] nec torrens, quamvis effusa sit "Não é violenta [a oração de Papírio Fabiano] nem torrencial, conquanto a queiras difusa").

59 Cf. Hor. AP 361-5: Vt pictura poesis: erit quae si propius stes / te capiat magis, et quaedam si longius abstes. / haec amat obscurum, volet haec sub luce videri, / iudicis argutum quae non formidat acumen; / haec placuit semel, haec decies repetita placebit "Como a pintura, a poesia. Existirá a que, se mais perto te atenhas, / mais te cative, e alguma, se mais longe te mantiveres; / esta ama o escuro; quer ser vista sob a luz aquela, / que a agudeza arguta do juiz não intimida; / uma aprouve uma vez; outra, dez vezes repetida, aprazerá”.

60 Também Cícero acusa esse erro na recepção do discurso humilde. Pois este, segundo o Orador, é tido, não raro, por fácil, quando quem ouve toma por simplório o que na verdade é simples; isso, porém, faz por desavisado, pois para quem fala a elaboração do discurso humilde é, quiçá, a mais difícil:

Itaque eum [sc. summissum et humilem] qui audiunt, quamvis ipsi infantes sint, tamen illo modo confidunt se posse dicere. Nam orationis subtilitas imitabilis illa quidem videtur esse existimanti, sed nihil est experienti minus (CIc. Or. 23 76)

$\mathrm{E}$ assim os que o ouvem [remisso e humilde], conquanto eles próprios sejam infacundos, contudo fiam que possam discursar daquele modo. Pois aquela sutileza da oração bem parece ser imitável a quem examina, mas nada [o] é menos a quem experimenta.

61 Cic. De or. 219 79: agere ac pronuntiare "atuar e pronunciar"; 357 216: Omnis enim motus animi suum quendam a natura habet vultum et sonum et gestum "Todo movimento anímico, sim, tem da natureza algum seu vulto, som, gesto”; Or. 17 55: [...] vocis [...] sonum, de quo plura dicerem [...]. Dicerem etiam de gestu, cum quo iunctus est vultus "[...] som [...] da voz de que mais coisas diria [...]. Diria ainda do gesto, junto com o qual está o vulto"; Her. 3 19: de uoce et uultu et gestu "da voz, vulto, gesto"; ib.: Diuiditur igitur pronuntiatio in uocis figuram et in corporis motum "Divide-se, logo, a pronunciação em configuração da voz e em movimento do corpo"; 3 26: Motus est corporis gestus et uultus moderatio "Movimento do corpo é moderação do gesto e vulto".

62 O Filósofo nota como alguns efeitos do discurso de Papírio Fabiano aparecem mais em audição presente do que em leitura posterior: Et fere quae impetu placent minus praestant ad manum relata (100 3) "E, preferencialmente, o que apraz pelo ímpeto [de quem discursa] presta-se menos a relatar-se pela mão [de quem escreve]”. Ainda assim, aquilo da ação que se aplica de modo particular ao diálogo pode aplicar-se de modo geral à epístola (cf. 75 1-2).

63 Também Cícero dá ao orador o explorar toda a gama de vozes, vultos e gestos:

Omnis sonorum tum intendens tum remittens persequetur [sc. ille princeps] gradus. Idemque motu sic utetur, nihil ut supersit. In gestu [...] (CIC. Or. 18 59) 
Persiga [aquele orador primeiro] toda graduação de sons, ora ascendente, ora descendente. Identicamente, use do movimento de tal modo que nada sobre. No gesto [...].

64 Cf. Cic. Off. 138 136: Sic eius modi motibus sermo debet vacare, ne aut ira existat aut cupiditas aliqua aut pigritia aut ignavia aut tale aliquid appareat, maximeque curandum est ut eos, quibuscum sermonem conferemus, et vereri et diligere videamur "Assim, de movimentos desse tipo a conversa deve ser vazia, para que se não exiba ira nem alguma cobiça nem preguiça nem ignávia, nem apareça algo que tal, e principalmente é para procurarmos parecer tanto reverentes como diligentes para com aqueles com que entabulamos conversa”.

65 Cícero tanto fala em uocis genus remissum (CIC. De or. 358 219) como em uox submissa, que associa, ademais, ao discurso lenis (id. Or. 17 58). Cf.: id. Or. 25 85: Itemque si quae verborum iterationes contentionem aliquam et clamorem requirent, erunt ab hac summissione orationis alienae "E identicamente, se algumas reiterações de palavras requererem alguma contenda e clamor, alheias serão a esta oração remissa”.

66 Cic. Or. 18 59: brachii proiectione in contentionibus, contractione in remissis "com projeção do braço nas contendas, com contração no remisso".

67 Cf. Her. 3 23: Sermo est oratio [...] finitima cottidianae locutioni "Conversa é oração [...] confinante com a locução cotidiana"; 4 17: in sermone et consuetudine cottidiana "Em conversa e costume cotidiano"; supra n. 9.

68 Também outros se põem a favor da dissimulação da arte na medida em que se opõem, não à arte, mas à ostentação desta; por exemplo, o pai de Sêneca e Quintiliano:

Et nescio an maximum vitium subtilitatis sit nimis se ostendere. Magis nocent insidiae quae latent: utilissima est dissimulata subtilitas (SEN. Contr. 1 praef. 21)

E não sei se o maior vício da sutileza é o ostentar a si mesma demasiado. Mais nocivas são as insídias latentes; a mais útil é a sutileza dissimulada;

Propter quod minime ostentari debet [...] cura (Quint. 4 1 56)

Pelo que jamais se deve ostentar o cuidado;

Sed uel propter hoc ipsum ostentanda non sunt, quod apparent (id. 129 6)

Mas talvez por isto mesmo não são para ostentar: porque aparecem.

69 Da dissimulação da arte falam autores gregos e latinos não só anteriores mas posteriores a Sêneca. Por exemplo, em latim, fala, muito antes de Sêneca, Cícero (cf. Cic. Or. 42 145: dissimulat) e, pouco antes, o pai de Sêneca (cf. Sen. Contr. 1 praef. 21: dissimulata); fala, depois, Quintiliano (cf. Quint. 217 6: dissimulator; 41 9: simulatio; 129 5: dissimulare). 
70 Quanto a quem fala, Cícero dá licença para patentear os procedimentos de elaboração do discurso (Cıc. Or. 12 38: aperte ac palam elaboratur) aos sofistas (cf. id. Or. 12 38: Isocrates; 12 39: Thrasymachum; ib.: Gorgiam; ib.: Theodorum), na medida em que estes se ocupam, não com a verdade das causas (cf. id. Or. 12 38: in veritate causarum), isto é, com o verdadeiro e falso do ensinar, mas com a volúpia dos ouvidos (cf. id. Or. 12 38: ad voluptatem aurium), isto é, com o prazeroso e fastidioso do deleitar (cf. id. Or. 19 65). Quanto a quem ouve, Quintiliano diz que os juízes que preferem os discursos em que se ostenta a arte são os que querem ser não só ensinados mas deleitados (cf. Quint. 41 57: Nec doceri tantum, sed etiam delectari uolunt "E querem ser não só ensinados, mas ainda deleitados"). Assim, é do ofício o dissimular bem como o ostentar a arte, pois cada um é adequado a cada fim:

Propterea quod in dicendo leuiter unus quisque locus plerumque tangitur, ne ars appareat, in praecipiendo expresse conscripta ponere oportet exempla uti in artis formam conuenire possint (Her. 4 10)

Bem porque no discursar o mais das vezes cada lugar é tocado levemente, para que não apareça a arte; no preceituar importa apor exemplos escritos expressamente, para que possam conformar-se à arte.

71 Cf. Her. 1 17: Et suspicionem adfert auditori meditationis et artificii "E confere ao ouvinte suspeita de premeditação e artifício”; Cic. Inu. 118 25: Propterea quod ex his suspicio quaedam apparationis atque artificiosae diligentiae nascitur "Bem porque destes nasce alguma suspeita de preparação e diligência artificiosa”; De or. 237 156: Suspicionem artifici apud eos, qui res iudicent, oratori adversariam esse arbitror "Admito que seja adversa ao orador a suspeita de artifício da parte dos que julgam o caso"; Inu. 152 98: suspicionem; De or. 237 156: suspicionem; Br. 37 139: suspicio; Or. 42 145: suspecta; QuiNT. 41 56: suspecti; 42 126: suspicio; 94 144: suspicio; 92 59: suspectos; 129 5: suspectae.

72 Cic. Or. 42 145: Propterea quod prudentia hominibus grata est, lingua suspecta "Bem porque a prudência é grata aos homens; a língua, suspeita”.

73 É a fidedignidade, segundo o pai de Sêneca, o fim da dissimulação da arte: Quod summae fiduciae est (SEN. Contr. 1 praef. 21) "O que é de suma fidedignidade", com o que concorda Quintiliano:

Veteribus quidem etiam dissimulare eloquentiam fuit moris, idque M. Antonius praecipit, quo plus dicentibus fidei minusque suspectae aduocatorum insidiae forent (QuinT. 129 5)

Dos antigos, sim, foi até costume dissimular a eloqüência, e isso M. Antônio preceituou, para que mais fidedignidade houvesse nos que discursam, e menos suspeitas fossem as insídias dos advogados.

A mesma fidedignidade, porém, bem como a autoridade, é o que, segundo Cícero, a ostentação da arte tolhe do discurso e do discursador: 
Quae [sc. suspicio quaedam apparationis atque artificiosae diligentiae] maxime orationi fidem, oratori adimit auctoritatem (CIC. Inu. 118 25)

A qual [suspeita de preparação e diligência artificiosa] à oração expropria a fidedignidade; ao orador, principalmente a autoridade;

Imminuit [sc. suspicio artifici] enim et oratoris auctoritatem et orationis fidem (id. De or. 237 156)

[A suspeita de artifício] diminui, sim, tanto a autoridade do orador como a fidedignidade da oração.

Daí, o cuidado, segundo Quintiliano, opõe-se à fidedignidade do discurso:

Magis perdit utique et fidem et adfectus motusque omnis qui est in hac cura deprensus, nec potest ei credere aut propter eum dolere et irasci iudex cui putat hoc uacare (Quint. 94 143)

Mais perde, decerto, tanto a fidedignidade como os afetos e comoções todas quem foi surpreendido nesse cuidado, e aquele que o juiz pensa vagar a isso, nele não pode crer nem por ele doer-se ou irar-se.

Ora, é nesse sentido que Sêneca repudia ao accuratum, bem como ao fictum (cf. supra); comparem-se, a propósito, estas palavras do Filósofo: Quae [sc. epistulae meae] nihil habent accersitum nec fictum (75 1) "As quais [=minhas epístolas] nada têm de rebuscado nem de forjado”, com estas de Quintiliano: Nihil uideatur fictum, nihil sollicitum (Quint. 42 126) "Nada pareça forjado, nada solícito”.

74 Cf. Cic. Or. 23 78: Sed quaedam etiam neglegentia est diligens "Mas é diligente ainda alguma negligência"; Br. 37 140: Itaque diligenter loquendi laude caruit "E assim diligentemente careceu de fala louvável”; supra n. 31-3.

75 Cf. Sen. Contr. 10 praef. 14: Partem esse eloquentiae putabat [sc. Caesar Augustus] eloquentiam abscondere "Pensava [César Augusto] ser parte da eloqüência o esconder a eloqüência"; QUINT. 111 3: Nam si qua in his ars est dicentium, ea prima est, ne ars esse uideatur "Pois se, quiçá, nisso existe arte de discursar, tal é a primeira: que não pareça ser arte"; 41 57: Sed ipsum istud euitare summae artis "Mas isso mesmo evitar é de suma arte"; 94 144: $\langle E t\rangle$ quidem illa maximi laboris, ne laborata uideantur "E, sim, aquilo é do maior labor: que não pareça ter-se elaborado".

76 Cf. SEN. Contr. 1 praef. 21: Nihil est iniquius his qui nusquam putant esse subtilitatem nisi ubi nihil est praeter subtilitatem; et in illo cum omnes oratoriae virtutes essent, hoc fundamentum superstructis tot et tantis molibus obruebatur, nec deerat in illo sed non eminebat "Nada é mais iníquo que esses que nunca pensam haver sutileza senão lá onde nada há afora sutileza, e como nele [=Latrão] todas as virtudes oratórias existissem, essa fundação era obstruída pela superestrutura de tanta e tamanha massa, e não era ausente nele, mas não eminente"; QUINT. 42 127: At hoc pati non possumus, et perire 
artem putamus nisi appareat, cum desinat ars esse, si apparet "Já isso não podemos suportar, e pensamos perecer a arte se não aparece, quando a arte deixa de ser se aparece".

77 Cf. Cic. Br. 37 139: Imparatus semper aggredi ad dicendum videbatur [sc. Antonius], sed ita erat paratus ut iudices illo dicente non numquam viderentur non satis parati ad cavendum fuisse "Parecia [Antônio] ingressar no discurso sempre despreparado, mas de tal modo estava preparado que os juízes, quando ele discursava, não raro pareciam insuficientemente preparados a precaver-se [dele]"; SEN. Contr. 1 praef. 21: Cum orationis cursus audientis iudicium impediat, dicentis abscondat "Já que o curso da fala oratória impede o juízo de quem ouve, esconde o de quem discursa”; QUINT. 42 59: Frigida uidentur ista plerisque, sed hoc ipso manisfestum est quo modo iudicem fefellerit [sc. Cicero], quod uix a lectore deprenditur. Haec sunt quae credibilem faciant expositionem "À maior parte isso parece frio, mas por isso mesmo se manifesta o modo como [Cícero] falseou o juiz, porque a custo o depreende o leitor. Isso é o que faz crível a exposição”.

78 Tal era o tratamento que Marco Antônio, dissimulador da arte (cf. Quint. 217 6), dava às palavras (cf. supra n. 77):

Verba ipsa non illa quidem elegantissimo sermone - itaque diligenter loquendi laude caruit neque tamen est admodum inquinate locutus -, sed illa, quae propria laus oratoris est in verbis, - nam ipsum Latine loqui est illud quidem [...] in magna laude ponendum, sed non tam sua sponte quam quod est a plerisque neglectum [...]; - sed tamen Antonius in verbis et eligendis, neque id ipsum tam leporis causa quam ponderis, et conlocandis et comprehensione devinciendis nihil non ad rationem et tamquam ad artem dirigebat; verum multo magis hoc idem in sententiarum ornamentis et conformationibus (Cic. Br. 37 140)

As próprias palavras não eram bem aquelas da mais elegante conversa - e assim diligentemente careceu [Antônio] de fala louvável e todavia não falou de modo impuro -, mas aquele [é] o louvor que é próprio do orador nas palavras, pois o próprio falar latino é bem aquilo [...] que é para ser muito louvado, mas não tanto por si próprio quanto porque é pela maior parte negligenciado [...]; mas nas palavras, contudo, Antônio, quer as elegesse - e isso não tanto por causa de polidez quanto de peso -, quer as colocasse, quer as vinculasse no período, nada deixava de dirigir para o cálculo e como que para a arte - [e] isso mesmo, em verdade, muito mais nos ornamentos e formas das sentenças -.

E que o abuso das figuras compromete a autoridade de quem fala, bem como a fidedignidade do que se fala, é o que se lê na Retórica a Herênio:

Quare fides et grauitas et seueritas oratoria minuitur his exornationibus frequenter conlocatis et non modo tollitur auctoritas dicendi, sed offenditur quoque in eiusmodi oratione (Her. 4 32)

Pelo que a fidedignidade, a gravidade, a autoridade oratória diminuem com esses ornamentos, [quando] freqüentemente colocados, e não só se tolhe a autoridade do discurso, mas se ofende também em oração desse tipo. 
79 Isso é o que se deve evitar, por exemplo, na partição, passo do discurso em que o discursador anuncia as partes da argumentação (cf. Her. 1 17), e na enumeração, passo em que se recapitulam as partes da argumentação (cf. Cic. De or. 152 98).

80 Cf. Quint. 94 144: Ideoque interim quaedam quasi soluenda de industria sunt "E por isso, às vezes, algumas coisas como que de indústria são para soltar"; 112 47: Idque in actionibus inter praecipua seruandum est ut quaedam etiam, quae optime uinximus, uelut soluta enuntiemus "E isto nas ações precipuamente é para observar: que enunciemos como solto mesmo algo que amarramos otimamente".

81 Quintiliano explica que quem fala com muita segurança patenteia ao ouvinte que o discurso que ora se declama já estava pronto e se sabia de cor:

Idque in actionibus inter praecipua seruandum est ut [...] cogitantibus nonnumquam et dubitantibus similes quaerere uideamur quae attulimus (QUINT. 112 47)

E isto, nas ações, precipuamente é para observar: que [...], semelhantes a quem não raro cogita e duvida, pareçamos indagar o que levamos ljá cogitado].

82 Sêneca opõe o sermo às disputationes praeparatae (38 1; cf. supra), e Quintiliano observa que quem ostenta segurança no discursar provoca a suspeita de quem ouve:

Quae simplicem quandam et non praeparatam ostendendo orationem minus nos suspectos iudici faciunt (QuINT. 92 59)

Que, por ostentar discurso algo simples e não preparado, nos faz menos suspeitos ao juiz;

Nam et magis miratur et minus timet iudex quae non putat aduersus se praeparata (id. 112 47)

Pois tanto mais admira como menos teme o juiz o que não pensa ter sido preparado contra si.

83 Cf. Sen. Contr. 1 praef. 21: Utilissima est dissimulata subtilitas, quae effectu apparet, habitu latet "A mais útil é a sutileza dissimulada, que é aparente pelo efeito, latente pelo modo".

84 Sobre entender-se como efeito (cf. QuinT. 62 32: adfectus), enárgeia entende-se, ademais, como preceito da narração (id. 62 32) ou ainda como ornamento (id. 83 61) ou figura (id. 92 40). Cf. Cic. De or. 353 202; Part. 620.

85 Cf. Quint. 83 62: Magna uirtus res de quibus loquimur clare atque ut cerni uideantur enuntiare "Grande virtude o enunciar as coisas, de que falamos, tão claramente que pareçam ser contempladas”; Cic. De or. 353 202: inlustris explanatio rerumque, quasi gerantur, sub aspectum paene subiectio "o explanar ilustrativo e o quase sujeitar as 
coisas, como se se produzissem, ao conspecto"; Part. 6 20: Est enim plus aliquanto inlustre quam illud dilucidum. Altero fit ut intellegamus, altero ut videre videamur "É, sim, algo mais ilustrativo que aquele elucidativo. Por um se faz que entendamos, pelo outro que pareçamos ver".

86 Também como referência a efeitos mais que a fatos poderiam entender-se os seguintes passos de Sêneca:

Hoc unum plane tibi adprobare vellem, omnia me illa sentire quae dicerem, nec tantum sentire sed amare (75 3)

Isto unicamente eu gostaria de provar-te com plenitude: que sentia tudo o que dizia, e não apenas sentia mas amava;

Haec sit propositi nostri summa: quod sentimus loquamur, quod loquimur sentiamus; concordet sermo cum vita (75 4)

Seja este o sumo do nosso propósito: falemos o que sentimos, sintamos o que falamos; concorde a conversa com a vida;

Denique illud praestabit, ut liqueat tibi illum sensisse quae scripsit (100 11)

Enfim, isto sobressairá: a clareza de ter ele sentido o que escreveu.

\section{REFERÊNCIAS BibLIOGRÁficAS}

Cicero. Brutus. In: -. Rhetorica. Recognovit brevique adnotatione critica instruxit A. S. Wilkins. 3 ed. Oxford: Oxford University Press, 1988. t. 2.

-. De finibus. In: -. Opera quae supersunt omnia. Curaverunt I. C. Orellius et C. Halmius. 2 ed. Turici: Sumptibus ac typis Orellii, Füsslini et sociorum, 1861. v. 4, p. 76-206.

-. De inventione. In: -. Opera quae supersunt omnia. Curaverunt I. C. Orellius et I. G. Baiterus. 2 ed. Turici: Sumptibus ac typis Orellii, Füsslini et sociorum, 1845. v. 1, p. 88-172.

-. De officiis. In: -. Opera quae supersunt omnia. Curaverunt I. C. Orellius et C. Halmius. 2 ed. Turici: Sumptibus ac typis Orellii, Füsslini et sociorum, 1861. v. 4, p. $641-741$.

-. De optimo genere oratorum. In: -. Rhetorica. Recognovit brevique adnotatione critica instruxit A. S. Wilkins. 3 ed. Oxford: Oxford University Press, 1988. t. 2 . 
-. De oratore. In: -. Rhetorica. Recognovit brevique adnotatione critica instruxit A. S. Wilkins. 3 ed. Oxford: Oxford University Press, 1988. t. 1.

-. Epistolae ad Atticum. In: -. Opera quae supersunt omnia. Curaverunt I. C. Orellius et I. G. Baiterus. 2 ed. Turici: Sumptibus ac typis Orellii, Füsslini et sociorum, 1845. v. 3, p. 373-752.

-. Epistolae ad familiares. In: -. Opera quae supersunt omnia. Curaverunt I. C. Orellius et I. G. Baiterus. 2 ed. Turici: Sumptibus ac typis Orellii, Füsslini et sociorum, 1845. v. 3, p. 3-304.

-. Orator. In: -. Rhetorica. Recognovit brevique adnotatione critica instruxit A. S. Wilkins. 3 ed. Oxford: Oxford University Press, 1988. t. 2.

-. Partitiones oratoriae. In: -. Rhetorica. Recognovit brevique adnotatione critica instruxit A. S. Wilkins. 3 ed. Oxford: Oxford University Press, 1988. t. 2.

Horatius. Ars poetica. In: -. Opera. Recognovit brevique adnotatione critica instruxit E. C. Wickham. 20 ed. Oxford: Oxford University Press, 1989. p. 253-68.

-. Epistulae. In: -. Opera. Recognovit brevique adnotatione critica instruxit E. C. Wickham. 20 ed. Oxford: Oxford University Press, 1989. p. 203-52.

-. Sermones. In: -. Opera. Recognovit brevique adnotatione critica instruxit E. C. Wickham. 20 ed. Oxford: Oxford University Press, 1989. p. 133-201.

Quintilien. Institution oratoire. Texte établi et traduit par Jean Cousin. Paris: Les Belles Lettres, 1975-80. 7 t.

Rhétorique à Herennius. Texte établi et traduit par Guy Achard. Paris: Les Belles Lettres, 1989.

SeneCA. Lettere a Lucilio. Introduzione di Luca Canali. Traduzione e note di Giuseppe Monti. 4 ed. Milano: Bilblioteca Universale Rizzoli, 1991

The elder Seneca. Declamations. Translated by Michael Winterbottom. Cambridge: Harvard University Press, 1974. 2 t.

SANTOS, Marcos Martinho dos. Art dialogique et épistolaire selon les Épîtres de Sénèque.

RÉSUMÉ: Il s'agit de rassembler les préceptes relatifs au discours philosophique que Sénèque formule dans les Épîtres. D'abord, les préceptes du genre dialogique (sermo ou diálogos), duquel l'epistula est une des espèces. Ensuite, les préceptes de l'office d'enseigner, propre au philosophe, qui s'oppose alors au poète, auquel il convient de charmer, et à l'orateur, 
auquel il convient d'émouvoir. Enfin, les préceptes de l'art dialogique ou épistolaire, selon lesquels la matière philosophique doit être magnifique, et l'élocution, négligée. Cependant, cette négligence est véritablement diligence pour le philosophe; ou alors, elle n'est pas un défaut, mais l'effet même de l'élaboration du discours. L'art dialogique apparait, alors, comme une art de dissimuler l'art.

MOTS-CLÉS: dialogue; épître; discours philosophique; office d'enseigner; art dialogique; dissimulation de l'art. 